\title{
Paleomagnetic constraints on the timing and distribution of Cenozoic rotations in Central and Eastern Anatolia
}

\author{
Derya Gürer ${ }^{1}$, Douwe J. J. van Hinsbergen ${ }^{1}$, Murat Özkaptan ${ }^{2}$, Iverna Creton ${ }^{1}$, Mathijs R. Koymans ${ }^{1}$, \\ Antonio Cascella ${ }^{3}$, and Cornelis G. Langereis ${ }^{1}$ \\ ${ }^{1}$ Department of Earth Sciences, Utrecht University, 3584 CD Utrecht, the Netherlands \\ ${ }^{2}$ Department of Geophysical Engineering, Karadeniz Technical University, 61080 Trabzon, Turkey \\ ${ }^{3}$ Istituto Nazionale di Geofisica e Vulcanologia (INGV), 56126 Pisa, Italy
}

Correspondence: Derya Gürer (derya.guerer@gmail.com)

Received: 26 June 2017 - Discussion started: 3 July 2017

Revised: 17 January 2018 - Accepted: 7 February 2018 - Published: 21 March 2018

\begin{abstract}
To quantitatively reconstruct the kinematic evolution of Central and Eastern Anatolia within the framework of Neotethyan subduction accommodating Africa-Eurasia convergence, we paleomagnetically assess the timing and amount of vertical axis rotations across the Ulukışla and Sivas regions. We show paleomagnetic results from $\sim 30$ localities identifying a coherent rotation of a SE Anatolian rotating block comprised of the southern Kırşehir Block, the Ulukışla Basin, the Central and Eastern Taurides, and the southern part of the Sivas Basin. Using our new and published results, we compute an apparent polar wander path (APWP) for this block since the Late Cretaceous, showing that it experienced $\mathrm{a} \sim 30-35^{\circ}$ counterclockwise vertical axis rotation since the Oligocene time relative to Eurasia. Sediments in the northern Sivas region show clockwise rotations. We use the rotation patterns together with known fault zones to argue that the counterclockwise-rotating domain of south-central Anatolia was bounded by the Savc1lı Thrust Zone and Deliler-Tecer Fault Zone in the north and by the African-Arabian trench in the south, the western boundary of which is poorly constrained and requires future study. Our new paleomagnetic constraints provide a key ingredient for future kinematic restorations of the Anatolian tectonic collage.
\end{abstract}

\section{Introduction}

The Anatolian orogen in the eastern Mediterranean region is comprised of a complex collage of ocean- and continent-derived crustal units that amalgamated during Africa-Eurasia convergence and associated subduction since the Mesozoic that today forms a nascent orogenic plateau (e.g., Schildgen et al., 2012). One of the most striking features in Anatolian geology are two major strike-slip faults, along which Anatolia is moving westwards relative to Eurasia, associated with major seismicity. This complex orogen with its major seismic hazards has been extensively studied to develop dynamic concepts to explain late Neogene escape tectonics (e.g., Gürsoy et al., 2011), plateau rise, and in deeper geological times, subduction initiation and evolution (e.g., Gürer et al., 2016).

An essential ingredient for analysis of the geodynamic underpinnings of orogenic evolution is a detailed kinematic restoration of deformation that culminated in today's orogen. Quantitative kinematic data for such reconstructions come from global plate reconstructions to constrain convergence through time, structural geology to estimate the timing, style, and the amount of fault displacements in the orogen, and paleomagnetic constraints on amount, distribution, and timing of vertical axis block rotations. Together, such constraints allow for an estimation of how convergence was partitioned over the orogen and help to identify the location, timing, and amount of subduction during orogenesis.

The Anatolian collage may in its simplest form be subdivided into two major belts (Fig. 1): the Pontide foldand-thrust belt in the north, which has formed the south- 


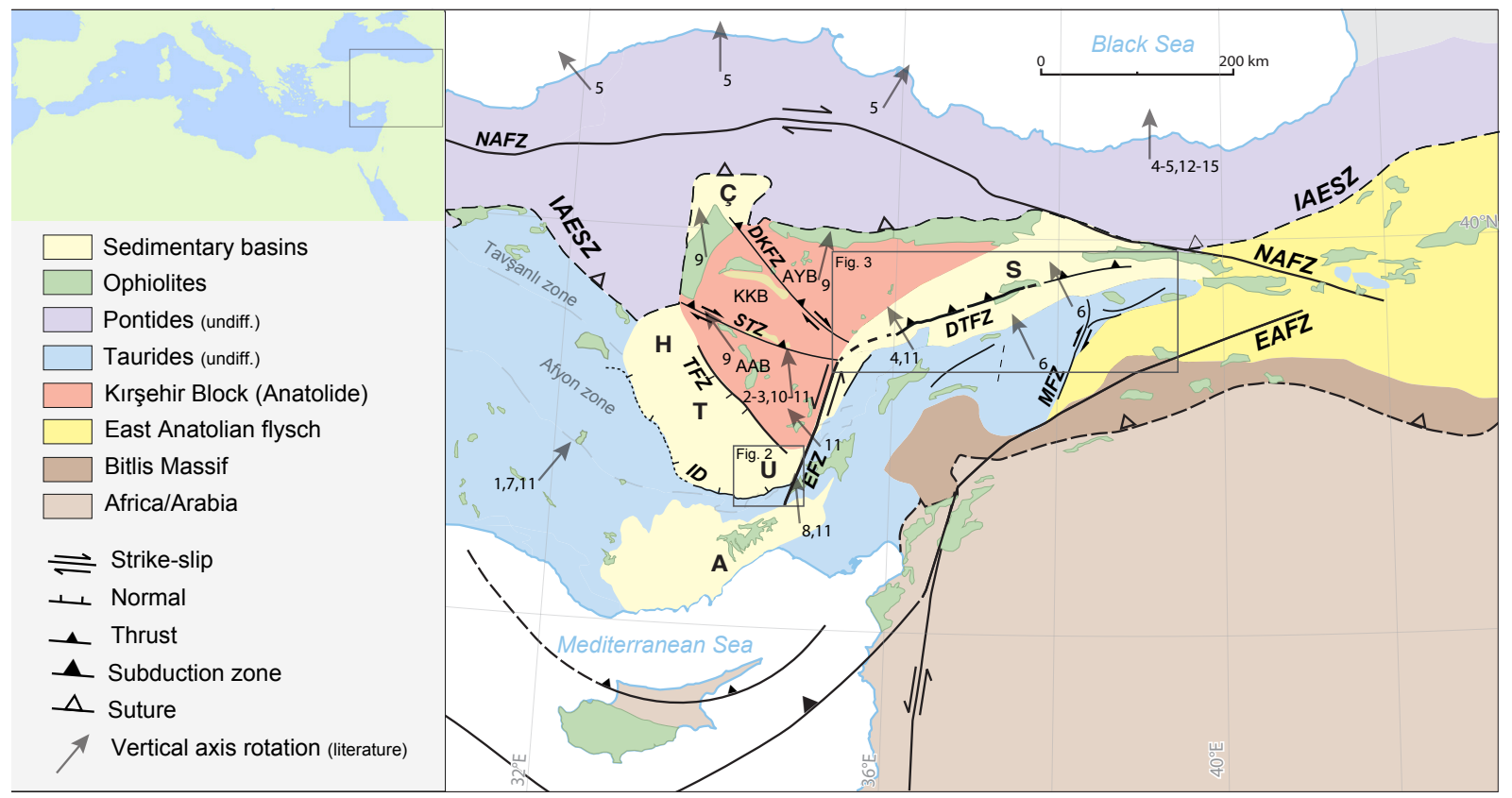

Figure 1. Tectonic units, associated suture zones, and main fault zones within the Anatolian microplate. Available vertical axis rotations are shown as arrows, and the corresponding references are as follows. 1: Kissel et al., 1993; 2: Platzman et al., 1998; 3: Piper et al., 2002a, b; 4: Kissel et al., 2003; 5: Meijers et al., 2010a; 6: Gürsoy et al., 2011; 7: Meijers et al., 2011; 8: Lucifora et al., 2012; 9: Lefebvre et al., 2013; 10: Piper et al., 2013; 11: Çinku et al., 2016, 12: Baydemir, 1990; 13: Channell et al., 1996; 14: Orbay and Bayburdi, 1979; 15: van der Voo, 1968. Locations of the sedimentary basins mentioned: Ulukışla (U), Sivas (S), Haymana (H), Tuzgölü (T), Çankırı (Ç), Adana (A). Major faults: Ecemiş Fault Zone (EFZ), Deliler-Tecer Fault Zone (DTFZ), Savcılı Thrust Zone (STZ), Tuzgölü Fault (TFZ), North Anatolian Fault Zone (NAFZ), East Anatolian Fault Zone (EAFZ), Malatya Fault Zone (MFZ), Ivriz Detachment (ID). The Kirşehir Block consists from north to south of the Akadağ-Yozgat Block (AYB), the Kırşehir-Kırıkkale Block (KKB), and the Ağaçören-Avanos Block (AAB). Note that the $\mathrm{U}$ and $\mathrm{S}$ basins are offset along the EFZ. Map insets of the geology of the study regions between the Kırşehir Block and the Taurides and between the Kırşehir Block, the Eastern Pontides, and the Taurides are shown in Figs. 2 and 3.

ern Eurasian margin since at least the mid-Mesozoic (Dokuz et al., 2017; Nikishin et al., 2015; Şengör and Y1lmaz, 1981; Ustaömer and Robertson, 2010, 1997), and the AnatolideTauride belt in the south. This latter belt is thought to have derived from a microcontinental realm that was separated from Eurasia and Africa by ocean basins and consists of metamorphosed and non-metamorphosed tectonic units overlain by Cretaceous ophiolites. In Central Anatolia, the wider Anatolide-Tauride belt consists of (from north to south) the Kurşehir Block, the Afyon Zone, and the Tauride fold-andthrust belt (Fig. 1; Barrier and Vrielynck, 2008; Boztuğ et al., 2009; Menant et al., 2016; Moix et al., 2008; Parlak et al., 2012; Robertson, 2002; Robertson et al., 2009; van Hinsbergen et al., 2016). Ages of accretion, metamorphism, and exhumation are younging from north to south and range from Late Cretaceous to Eocene (Göncüoglu, 1997; Gürer et al., 2016; Okay and Tüysüz, 1999; van Hinsbergen et al., 2016). The Pontide and Anatolide-Tauride belts are separated by the Izmir-Ankara-Erzincan suture zone (IAESZ) that demarcates the former location of the now subducted Neotethys Ocean and that is thought to result from the latest Cretaceous to Paleogene collision of the Anatolide-Tauride and Pontide belts (Fig. 1; Şengör and Y1lmaz, 1981).

Previous paleomagnetic research has revealed that these major continent-derived units were in the Cenozoic time broken up into large structural blocks that underwent significant vertical axis rotations relative to one another and bounded by fault zones. The Pontides of Central Anatolia were deformed in the Paleogene time into a northward convex orocline (Meijers et al., 2010; Kaymakci et al., 2003; Çinku et al., 2011; Lucifora et al., 2013). Deformation was accommodated along thrusts associated with the IAESZ in the south and thrusts inverting the southern Black Sea margin in the north (Kaymakci et al., 2009; Espurt et al., 2014; Fig. 1). To the south, the Kirşehir Block broke into three rotating blocks: the northeastern Akdağ-Yozgat Block (AYB), the central Kırşehir-Kırıkkale Block (KKB), and the southern Avanos-Ağacören Block (AAB) as shown by paleomagnetic data from Upper Cretaceous granitoids (Lefebvre et al., 2013). These rotating blocks were bordered by transpressional fault zones active between the late Eocene and early Miocene (e.g., Gülyüz et al.,2013; Advokaat et al., 2014; Isik et al., 2014). In Southern and Eastern Anatolia, large rota- 
tions have been identified in the Taurides and overlying sedimentary basins (Çinku et al., 2016; Kissel et al., 1993, 2003; Meijers et al., 2011, 2016; Piper et al., 2002a; Fig. 1), but the regional coherence, block size, and bounding structures that accommodated these rotations are poorly defined.

In this paper, we aim to constrain the dimensions of the Cenozoic rotating domain(s) in Central and Eastern Anatolia, the timing of their rotation, and the structures that may have accommodated these rotations relative to surrounding blocks. To this end, we collected new paleomagnetic data from two major uppermost Cretaceous to Miocene sedimentary basins that overlie the Taurides and Kirşehir blocks: the Ulukışla and Sivas basins (Fig. 1). We combine our extensive new dataset with existing data to identify the dimensions of rotating domains in Central and Eastern Anatolia and identify structures that may have accommodated these rotations.

\section{Geological setting}

\subsection{Basement units}

The Pontides mountain belt in northern Turkey contains Gondwana-derived fragments that had collided with Eurasia by the mid-Mesozoic time (e.g., Okay and Nikishin, 2015; Şengör and Y1lmaz, 1981; Ustaömer and Robertson, 1997, 2010; Dokuz et al., 2017). Since at least Early Jurassic time, the Pontides became bounded to the south by a northwarddipping subduction zone (Okay et al., 2014; Topuz et al., 2014) that consumed Mesozoic Neotethyan oceanic crust.

The Kirşehir Block became underthrusted and metamorphosed in the Late Cretaceous time around 85-90 Ma due to ophiolite emplacement (Boztug et al., 2009; Whitney and Hamilton, 2004). Subsequently, around 70-65 Ma the Afyon Zone was accreted and metamorphosed (Özdamar et al., 2013; Pourteau et al., 2013). This was followed by the latest Cretaceous to Eocene accretion of the Tauride fold-andthrust belt that largely consists of carbonate nappes (Demirtasli et al., 1984; Gutnic et al., 1979; Monod, 1977; Özgül, 1984). The Taurides mostly escaped metamorphism and accreted, while the Kırşehir Block and Afyon Zone were exhumed by extension in the Late Cretaceous to early Eocene time (Gautier et al., 2002, 2008; Gürer et al., 2018; Isik, 2009; Isik et al., 2008; Lefebvre et al., 2011, 2015).

After the latest Cretaceous to Paleocene onset of collision of the Kirşehir Block with the Pontides and the closure of the IAESZ (Kaymakci et al., 2009), the Pontides and the Kırşehir Block broke into large blocks that rotated relative to each other. This started with the formation of the Pontides orocline in the Paleogene (Meijers et al., 2010). Further shortening and vertical axis rotations moved to the south (Çankırı Basin, Fig. 1) and continued until the early Miocene (Kaymakci et al., 2003, 2009; Lucifora et al., 2013; Espurt et al., 2014). East of the orocline and north of the Sivas Basin, the Pontides did not experience significant rotation since the Eocene (Meijers et al., 2010a, and references therein).

The Kirşehir Block broke into three sub-blocks separated by fault zones (Lefebvre et al., 2013; Fig. 1). The AAB in the south and KKB in the northwest were separated by the Savcilı Thrust Zone (STZ), which is a sinistral structure that underwent contraction between $\sim 40 \mathrm{Ma}$ and at least $\sim 23 \mathrm{Ma}$ (Isik et al., 2014; Advokaat et al., 2014), and the KKB and the AYB in the northeast were separated by the Delice-Kozakli Fault Zone (DKFZ) that was postulated to be a dextral, transpressional structure with an estimated offset of up to $90 \mathrm{~km}$ (Lefebvre et al., 2013; Fig. 1). To the west, the Kırşehir Block is bordered by the Tuzgölü Fault Zone (TFZ; Fig. 1), which contains a large normal fault displacement of at least Eocene and younger age (Çemen et al., 1999).

The Taurides to the south are bent into an orocline, with clockwise rotations in the western-central Taurides (Kissel et al., 1993; Meijers et al., 2011; Çinku et al., 2016; Piper et al., 2002a, b) and counterclockwise rotations reported from the Eastern Taurides (Çinku et al., 2016; Kissel et al., 2003). The Eastern Taurides are cut by NNE-SSW-trending strike-slip faults. The most western of these is the Ecemiş Fault Zone (EFZ; Figs. 1 and 2) that separates the Kırşehir Block and Central Taurides to the west and the Eastern Taurides to the east (e.g., Jaffey and Robertson, 2001). It also left-laterally disrupts the connection between the Ulukışla and Sivas basins from the Eocene-Oligocene time onward (Gürer et al., 2016). To the south, lower Miocene sediments in the Adana Basin (A in Fig. 1) seal the strike-slip component of the Ecemiş Fault Zone, which after the early Miocene time only experienced E-W-directed normal faulting with only a minor strike-slip component (Alan et al., 2011; Higgins et al., 2015; Jaffey and Robertson, 2001; Sarıkaya et al., 2015).

\subsection{Sedimentary basins flanking the Northern Taurides}

Several sedimentary basins developed on top of the sutures and recorded the geological evolution of the Anatolian orogen from the Late Cretaceous to present. Broad similarities in their stratigraphy suggest that the Upper CretaceousPaleogene stratigraphic record of the Ulukışla and Sivas basins once formed a contiguous basin. Both overlie the Cretaceous ophiolites and contain stratigraphies that overlap in time with thrusting, metamorphism, exhumation, and accretion of the underlying Tauride units (Akyuz et al., 2013; Clark and Robertson, 2002, 2005; Gürer et al., 2016; Poisson et al., 1996). The Ulukışla and Sivas basins became separated due to displacement along the Ecemiş Fault Zone in the late Eocene-Oligocene (Figs. 1-3).

The Ulukışla Basin (Fig. 2) contains a discontinuous stratigraphic record of a laterally variable series of shallow and deeper marine clastic and carbonate sediments interlayered with volcanic rocks overlain by continental coarse clastic rocks. The deposits range from the latest Cretaceous to 


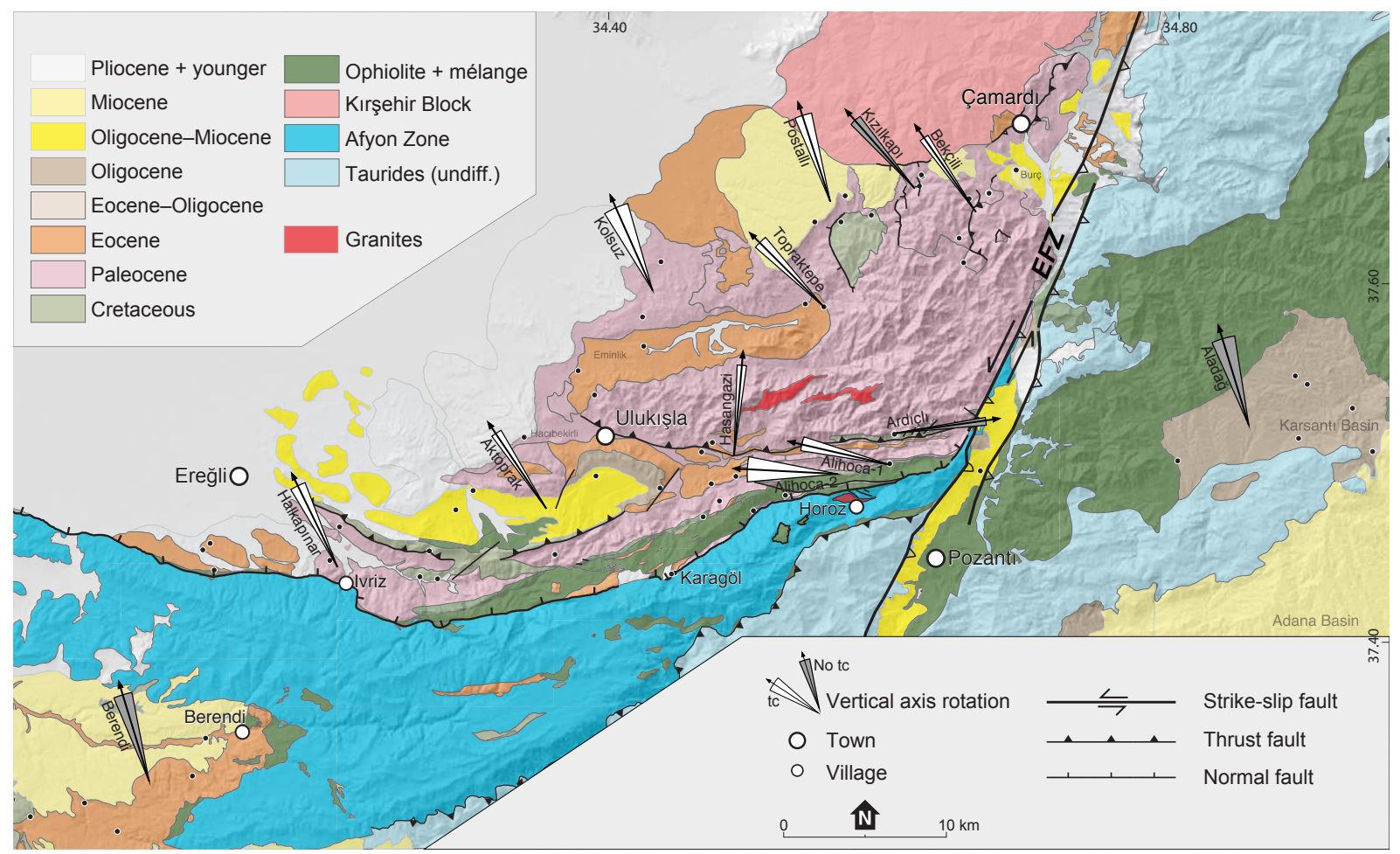

Figure 2. Geological map of the Ulukışla Basin (modified after Gürer et al., 2016) with major tectonic structures. Individual sampling sites are shown as black dots, and localities and associated vertical axis rotations are denoted as arrows with their $95 \%$ error envelope $\left(\Delta D_{x}\right)$.

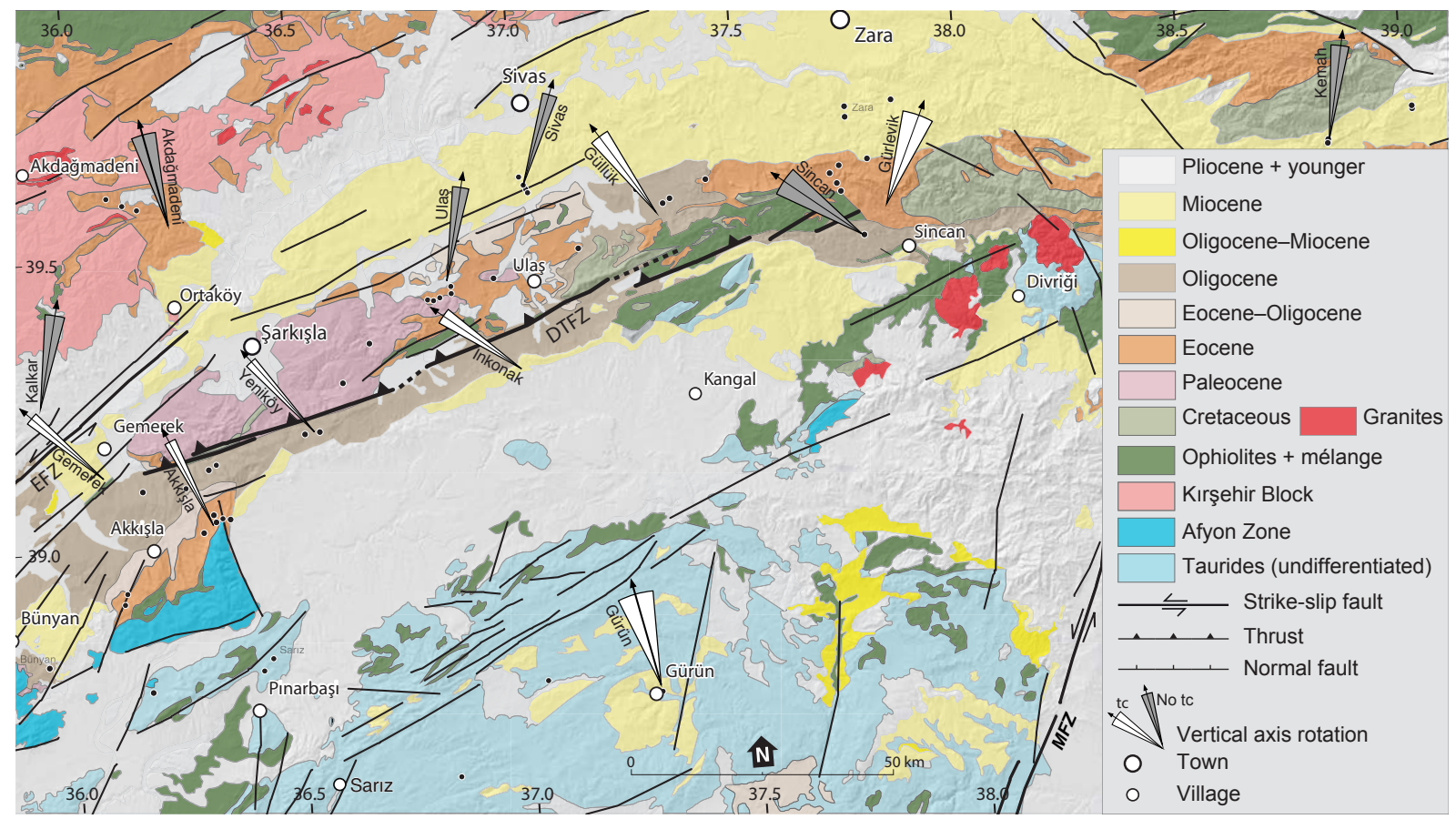

Figure 3. Geological map of the Sivas Basin with major tectonic structures (modified from MTA, 2002). Symbols are as in the caption to Fig. 2. 
Miocene in age and unconformably overlie ophiolitic basement. Eocene and younger rocks of the basin also unconformably overlie metamorphic rocks of the Kırşehir Block and the Afyon Zone. In the Late Cretaceous time, the basin developed above the Alihoca ophiolites during the burial of the Afyon Zone below these ophiolites. From this context, the basin is interpreted as a forearc basin. During extensional exhumation of the Afyon Zone along the top-to-thenorth Ivriz Detachment (Fig. 1), the basin underwent N-S extension in the detachment's hanging wall and underwent widespread marine clastic deposition (Gürer et al., 2016, 2018). At the northern basin margin and close to the contact with the Kırşehir Block, a series of large-offset listric normal faults are compatible with E-W extension (in present-day coordinates). These offset sediments and the base of Paleocene volcanics indicate that $\mathrm{E}-\mathrm{W}$ extension occurred simultaneously with $\mathrm{N}-\mathrm{S}$ extension in the south, which prevailed until at least $56 \mathrm{Ma}$ (Gürer et al., 2018). Following extension and exhumation, the late Eocene-Oligocene history of the basin involved $\mathrm{N}-\mathrm{S}$ shortening, especially in the southern part of the basin, resulting in the formation of a north-verging fold with a widely exposed subvertical to overturned northern limb that marks the southern exposures of the Ulukışla Basin and subordinate top-to-the-south thrusting in the synclinal hinge zone. Westward, these folds become more open and structures become gradually NE-SW oriented, while several anticlines and synclines deform the basal stratigraphy of the basin. The Oligocene redbeds in the Aktoprak syncline (Meijers et al., 2016) in the southwestern part of the Ulukışla Basin are interpreted as having been deposited during folding (Gürer et al., 2016). To the east, the folded Ulukışla Basin sediments curve towards NE-SW strikes interpreted to reflect drag folding against the major left-lateral EFZ (Gürer et al., 2016).

The Sivas region (Figs. 1 and 3) hosts a depocenter bound by the Pontides to the north, the Kırşehir Block-EFZ in the west, and the Taurides in the south. Its eastern boundary is diffuse. To the south, on the northern flanks of the Tauride fold-and-thrust belt, ophiolites are unconformably overlain by uppermost Cretaceous to Eocene, dominantly marine carbonate and clastic sediments and Paleocene volcanic and volcaniclastic rocks. These sediments were affected by northverging Paleocene-Eocene thrusting (Cater et al., 1991; Poisson et al., 1996; Yilmaz and Yilmaz, 2006), possibly related to the so far structurally poorly reconstructed thrusting in the Tauride fold-and-thrust belt underneath. In the late Eocene-Oligocene, sedimentation became terrestrial to lacustrine. This overall sequence shows first-order similarities with the Ulukışla Basin.

The younger stratigraphy, however, is significantly different and is located to the north of a large fault zone that runs through the center of the Sivas Basin (Figs. 1 and 3). This fault zone consists of a series of thrusts and towards the west connects to the EFZ through a series of NE-SW-striking sinistral strike-slip faults (Higgins et al., 2015; Fig. 3). To the east, the fault is defined by a $60^{\circ} \mathrm{N}-70^{\circ} \mathrm{E}$ trend with a leftlateral strike-slip component (Yilmaz and Yilmaz, 2006; Akyuz et al., 2013) that thrusts ophiolites and Cretaceous and younger sediments over folded Oligocene redbeds to the south, all along the strike of the Sivas Basin. This structure is hereafter referred to as Deliler-Tecer Fault Zone (DTFZ; Figs. 1 and 3).

In the hanging wall of the DTFZ, the northern Sivas Basin is an elongated depocenter comprised of Oligocene to Pliocene continental and marine strata including widespread Miocene evaporites overlain by continental redbeds. Salt mobility led to strong local deformation and the formation of mini-basins (Callot et al., 2014; Kergaravat et al., 2016; Pichat et al., 2016; Poisson et al., 2016; Ribes et al., 2015). In the west, upper Miocene to recent volcanic rocks are found close to the EFZ and its connection to the Sivas fold-andthrust belt (Cater et al., 1991; Poisson et al., 1996; Yilmaz and Yilmaz, 2006). The subhorizontal Pliocene covers parts of the Sivas Basin on both sides of the DTFZ.

\section{Methods}

\subsection{Sampling}

An extensive sample set was obtained from 21 localities comprised of a total of 121 sites in rocks of common age from structurally coherent regions and totalling 2118 oriented paleomagnetic cores across the Upper Cretaceous to Miocene stratigraphy of the Ulukışla and Sivas basins and sediments overlying the Tauride fold-and-thrust belt (Figs. 2 and 3, Table 1; GPS locations of all sites are supplied in the Supplement). All samples were collected from sedimentary rocks. Age constraints for the sampled units come from geological maps and accompanying explanatory notes (MTA, 2002). Ages were complemented where available by published biostratigraphic literature (Blumenthal, 1956; Oktay, 1973, 1982; Demirtasli et al., 1984; Atabey et al., 1990; Clark and Robertson, 2005; Gürer et al., 2016). In a few cases, we obtained new nannofossil biostratigraphy (details supplied in the Supplement). Paleomagnetic samples were collected from marine sediments (limestones, marls, and turbiditic sandstones) of Late Cretaceous to middle Eocene and Miocene age, as well as continental clastic rocks of Oligocene and Miocene age. The samples were collected by drilling standard cores $(25 \mathrm{~mm} \varnothing)$ with a gasoline-powered, water-cooled drill. Cores were oriented using a magnetic compass, and drilling orientation and bedding plane were corrected for the local declination of $5^{\circ} \mathrm{E}$. We always sampled over a sufficiently long interval $(10-30 \mathrm{~m})$ per site, enough to sample paleosecular variation (PSV). In the laboratory, the cores were cut into specimens of $22 \mathrm{~mm}$ length using a double-blade circular saw. 
Table 1. Paleomagnetic results presented in this study and localities compiled from literature review. Lat/Long $\left(^{\circ}\right)$ : the latitude and longitude of sites and localities, $N_{\mathrm{a}}$ : number of samples analyzed, $N_{\mathrm{i}}$ : number of samples interpreted, $N_{45}$ : number of samples after application of a fixed cutoff $\left(45^{\circ}\right), D$ : declination, $I$ : inclination, $\Delta D_{x}$ : declination error, $\Delta I_{x}$ : inclination error, $K, A_{95}$ : Fisher (1953) precision parameter and cone of confidence of the mean virtual geomagnetic pole (VGP). $A_{95_{\min }}$ and $A_{95_{\max }}$ represent the confidence envelope of Deenen et al. (2011). If $A_{95}$ falls within this envelope the distribution likely represents paleosecular variation. Rot: amount of rotation relative to the north, $\Delta$ Rot: uncertainty in amount of rotation, cw: clockwise, ccw: counterclockwise. Rotations in black (white) are interpreted from a primary (secondary) magnetization. Sites indicated with "recent" carry a magnetization that has been recently acquired and are discarded. All site results are given in both geographic and tectonic coordinates, and locality results are given in either geographic or tectonic coordinates depending on our interpretation as explained in the text.

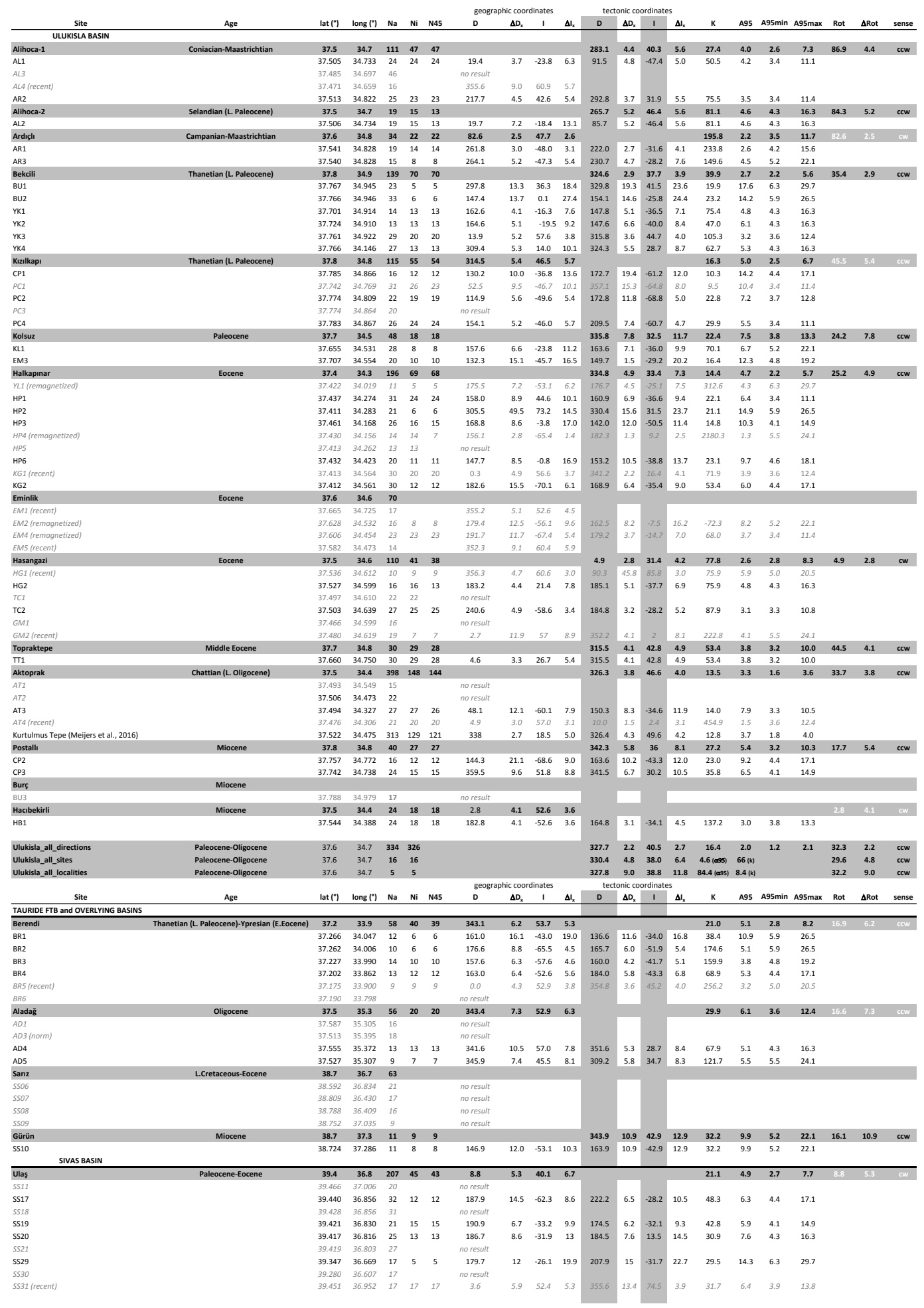


Table 1. Continued.

\begin{tabular}{|c|c|c|c|c|c|c|c|c|c|c|c|c|c|c|c|c|c|c|c|c|c|}
\hline Site & Age & lat $\left(0^{\circ}\right)$ & long $\left(^{\circ}\right)$ & $\mathrm{Na}$ & $\mathrm{Ni}$ & N45 & D & $\Delta \mathrm{D}_{\mathrm{x}}$ & $\mathrm{I}$ & $\Delta \mathrm{I}_{\mathrm{x}}$ & D & $\Delta D_{\mathrm{x}}$ & 1 & $\Delta I_{x}$ & $\mathrm{k}$ & A95 & A95min & A95max & Rot & $\Delta$ Rot & sense \\
\hline \multicolumn{22}{|l|}{ SIVAS BASIN (cont.) } \\
\hline Akkışla & Eocene & 39.0 & 36.2 & 126 & 95 & 89 & & & & & 333.6 & 3.4 & 30.1 & 5.3 & 21.9 & 3.3 & 2.0 & 4.8 & 26.4 & 3.4 & $\mathrm{ccw}$ \\
\hline ss1 & & 39.054 & 36.329 & 21 & 15 & 15 & 210.3 & 13.5 & -64.8 & 7.1 & 165.0 & 6.7 & -38.4 & 8.9 & 38.3 & 6.3 & 4.1 & 14.9 & & & \\
\hline SS4 (recent) & & 38.910 & 36.106 & 10 & 6 & 6 & 1.6 & 14.9 & 55.2 & 11.9 & 27.2 & 13.9 & 51.6 & 12.7 & 33.5 & 11.7 & 5.9 & 26.5 & & & \\
\hline ss5 & & 38.929 & 36.112 & 21 & 19 & 19 & 347.5 & 6.6 & 51.2 & 6.1 & 338.5 & 4.5 & 32.3 & 6.8 & 61.7 & 4.3 & 3.7 & 12.8 & & & \\
\hline SS25 & & 38.757 & 36.162 & 20 & 18 & 18 & 146.7 & 6.8 & -17.5 & 12.6 & 137.2 & 6.7 & -13.2 & 12.8 & 28.1 & 6.6 & 3.8 & 13.3 & & & \\
\hline SS27 & & 39.061 & 36.309 & 17 & 17 & 17 & 0.8 & 3.7 & 55.0 & 3.0 & 341.1 & 2.3 & 36.5 & 3.2 & 265.0 & 2.2 & 3.9 & 13.8 & & & \\
\hline sS55 & & 39.049 & 36.314 & 12 & 8 & 8 & 332.6 & 19.7 & 49.1 & 19.4 & 326.5 & 14.8 & 29.4 & 23.3 & 16.2 & 14.2 & 5.2 & 22.1 & & & \\
\hline 5556 & & 39.031 & 36.286 & 14 & 8 & & 355.0 & 10.4 & 44 & 12 & 342.0 & 7.1 & 23.0 & 12.3 & 35.9 & 9.4 & 5.2 & 22.1 & & & \\
\hline SS57 & & 39.053 & 36.346 & 11 & 10 & 10 & 336.0 & 12.1 & 33.9 & 17.6 & 342.1 & 27.6 & 65.6 & 13.7 & 8.1 & 18.1 & 4.8 & 19.2 & & & \\
\hline Gürlevik & Eocene & 39.6 & 37.7 & 76 & 20 & 19 & & & & & 199.8 & 9.5 & -40.2 & 12.1 & 15.6 & 8.8 & 3.7 & 12.8 & 19.8 & 9.5 & $\mathrm{cw}$ \\
\hline ss33 & & 39.605 & 37.712 & 18 & 12 & 11 & 217.0 & 17.0 & -44.3 & 19.4 & 186.2 & 15.4 & -38.4 & 20.2 & 11.2 & 14.2 & 4.6 & 18.1 & & & \\
\hline$S 536$ & & 39.627 & 37.798 & 18 & & & no result & & & & & & & & & & & & & & \\
\hline 5543 & & 39.617 & 37.733 & 18 & & & no result & & & & & & & & & & & & & & \\
\hline SS44 & & 39.587 & 37.727 & 12 & 8 & 8 & 205.7 & 5.2 & 6.4 & 10.4 & 207.2 & 7.7 & -41.4 & 9.5 & 62.2 & 7.1 & 5.2 & 22.1 & & & \\
\hline$S S 45$ & & 39.559 & 37.727 & 10 & & & no result & & & & & & & & & & & & & & \\
\hline Güllük & L.Eo-Oligocene & 39.6 & 37.3 & 69 & 24 & 24 & & & & & 322.4 & 10.7 & 53.9 & 9.0 & 12.2 & 8.8 & 3.4 & 11.1 & 37.6 & 10.7 & $\mathrm{ccw}$ \\
\hline$S 532$ & & 39.496 & 37.144 & 18 & 18 & 17 & 244.9 & 7.9 & -63.2 & 4.5 & 275.1 & 4.5 & -10.0 & 8.8 & 59.4 & 4.5 & 3.8 & 13.3 & & & \\
\hline ss51 & & 39.593 & 37.278 & 14 & 14 & 12 & 251.9 & 16.8 & -65.4 & 8.6 & 137.3 & 12.7 & -49.9 & 12.3 & 14.2 & 10.9 & 4.2 & 15.6 & & & \\
\hline$S 552$ & & 39.567 & 37.336 & 13 & 13 & 13 & 230.2 & 6.3 & 0.0 & 12.6 & 224.9 & 4.5 & -13.9 & 8.6 & 86.1 & 4.5 & 4.3 & 16.3 & & & \\
\hline$S 553$ & & 39.575 & 37.352 & 11 & 11 & 11 & 172.1 & 10.7 & -39.6 & 13.8 & 99.6 & 13.3 & -43.7 & 15.4 & 15.4 & 12.0 & 4.6 & 18.1 & & & \\
\hline SS54 & & 39.605 & 37.434 & 13 & 10 & 10 & 328.6 & 8.5 & 8.7 & 16.6 & 331.5 & 19.6 & 59.0 & 13.4 & 11.4 & 14.9 & 4.8 & 19.2 & & & \\
\hline Akdağmadeni & Eocene & 39.6 & 36.1 & 74 & 33 & 33 & 345.2 & 7.2 & 54.1 & 6.0 & & & & & 20.3 & 5.7 & 3.0 & 9.1 & 14.8 & 7.2 & $\mathrm{cow}$ \\
\hline Ss14 & & 39.613 & 36.093 & 31 & 22 & 22 & 160.7 & 9.6 & -51.7 & 8.7 & 163.7 & 6.8 & -22.1 & 11.9 & 22.7 & 6.7 & 3.5 & 11.7 & & & \\
\hline SS15 & & 39.600 & 36.128 & 21 & 11 & 11 & 175.0 & 8.1 & -58.0 & 5.8 & 185.4 & 5.6 & -34.8 & 7.9 & 76.4 & 5.3 & 4.6 & 18.1 & & & \\
\hline$S S 16$ & & 39.592 & 36.161 & 22 & & & no result & & & & & & & & & & & & & & \\
\hline Sincan & Oligocene & 39.5 & 37.8 & 16 & 16 & 16 & 304.2 & 9.0 & 47.8 & 9.3 & & & & & 22.6 & 6.4 & 4.0 & 14.3 & 55.8 & 9.0 & $\mathrm{cew}$ \\
\hline SS34 & & 39.496 & 37.783 & 16 & 16 & 16 & 304.2 & 9.0 & 47.8 & 9.3 & 277.5 & 6.6 & 25.7 & 11.0 & 22.6 & 6.4 & 4.0 & 14.3 & & & \\
\hline Yeniköy & Oligocene & 39.2 & 36.4 & 189 & 93 & 89 & & & & & 317.6 & 3.5 & 41.1 & 4.4 & 22.5 & 3.2 & 2.0 & 4.8 & 42.4 & 3.2 & $\mathrm{ccw}$ \\
\hline SSO2 & & 39.109 & 36.249 & 28 & 28 & 28 & 12.2 & 1.7 & 53.3 & 1.4 & 14.9 & 1.1 & 37.5 & 1.5 & 681.4 & 1.0 & 3.2 & 10.0 & & & \\
\hline $\mathrm{SSO}$ (recent) & & 39.147 & 36.318 & 22 & 18 & 18 & 355.6 & 3.6 & 53.7 & 3.1 & 347.3 & 1.9 & 12.2 & 3.7 & 321.5 & 1.9 & 3.8 & 13.3 & & & \\
\hline SS26 (recent) & & 39.105 & 36.153 & 21 & 21 & 21 & 10.1 & 2.9 & 54.6 & 2.4 & 2.3 & 3.3 & 57.5 & 2.4 & 148.6 & 2.6 & 3.6 & 12.0 & & & \\
\hline SS28 (recent) & & 39.139 & 36.301 & 5 & 5 & 5 & 0.3 & 9.6 & 53.0 & 8.3 & 350.7 & 21.9 & 24.1 & 37.3 & 13.8 & 21.3 & 6.3 & 29.7 & & & \\
\hline SS58 & & 39.198 & 36.551 & 5 & 5 & 5 & 314.5 & 11.0 & -9.5 & 21.5 & 311.6 & 14.5 & 35.1 & 20.6 & 32.3 & 13.7 & 6.3 & 29.7 & & & \\
\hline SS59 (recent) & & 39.195 & 36.518 & 6 & 5 & 5 & 6.2 & 8.2 & 59.1 & 5.6 & 43.6 & 8.7 & 61.1 & 5.5 & 141.1 & 6.5 & 6.3 & 29.7 & & & \\
\hline Yeniköy, Krijgsman et al. (1996) & & 39.200 & 36.500 & 102 & 88 & 84 & 306.2 & 3.1 & 26.2 & 5.1 & 318.0 & 3.7 & 41.5 & 4.5 & 22.2 & 3.4 & 2.0 & 5.0 & & & \\
\hline Inkonak & Upper Oligocene & 39.3 & 37.1 & 173 & 98 & 87 & & & & & 304.0 & 5.0 & 45.9 & 5.4 & 12.8 & 4.4 & 2.0 & 4.9 & 56.0 & 5.0 & $\mathrm{ccw}$ \\
\hline Inkonak & & 39.315 & 37.060 & 173 & 98 & 87 & 314.3 & 4.2 & 33.7 & 6.1 & 304.0 & 5.0 & 45.9 & 5.4 & 12.8 & 4.4 & 2.0 & 4.9 & & & \\
\hline Gemerek & Miocene & 39.200 & 36.000 & 99 & 76 & 71 & & & & & 310.1 & 3.8 & 36.6 & 5.2 & 23.1 & 3.6 & 2.2 & 5.6 & 49.9 & 3.8 & $\mathrm{ccw}$ \\
\hline Gemerek & & 39.163 & 36.048 & 99 & 76 & 71 & 156.4 & 10.2 & 66.4 & 5.0 & 310.1 & 3.8 & 36.6 & 5.2 & 23.1 & 3.6 & 2.2 & 5.6 & & & \\
\hline Bünyan & Miocene & 38.1 & 39.9 & 17 & 16 & 16 & & & & & & & & & & & & & & & \\
\hline SS24 (recent) & & 38.806 & 39.934 & 17 & 16 & 16 & 357.2 & 5.5 & 57.9 & 4.0 & 355.9 & 6.5 & 62.9 & 3.8 & 63.9 & 4.6 & 4.0 & 14.3 & & & \\
\hline Sivas & Miocene & 39.6 & 37.0 & 102 & 59 & 59 & 13.1 & 4.8 & 57.0 & 3.6 & & & & & 25.0 & 3.8 & 2.3 & 6.3 & 16.3 & 4.8 & $\mathrm{cw}$ \\
\hline SS12* & & 39.596 & 37.036 & 32 & 5 & 5 & 264.8 & 10.0 & -1.8 & 20.1 & 228.5 & 10.8 & -40.6 & 13.6 & 60.0 & 10.0 & 6.3 & 29.7 & & & \\
\hline SS13 & & 39.610 & 37.027 & 20 & 17 & 17 & 178.2 & 4.6 & -53.5 & 3.9 & 169.5 & 3.2 & -37.5 & 4.4 & 139.9 & 3.0 & 3.9 & 13.8 & & & \\
\hline SS22 & & 39.624 & 37.018 & 33 & 33 & 33 & 21.8 & 5.4 & 59.1 & 3.7 & 10.8 & 3.4 & 26.5 & 5.5 & 59.7 & 3.3 & 3.0 & 9.1 & & & \\
\hline SS23 & & 39.603 & 37.032 & 17 & 9 & 9 & 199.5 & 13.9 & -52.5 & 12.2 & 179.1 & 11.9 & -43.6 & 13.8 & 24.1 & 10.7 & 5.0 & 20.5 & & & \\
\hline Zara & Miocene & 39.7 & 37.8 & & & & & & & & & & & & & & & & & & \\
\hline$S S 35$ & & 39.718 & 37.753 & 11 & & & no result & & & & & & & & & & & & & & \\
\hline 5537 & & 39.727 & 37.857 & 11 & & & no result & & & & & & & & & & & & & & \\
\hline SS42 & & 39.700 & 37.752 & 13 & & & no result & & & & & & & & & & & & & & \\
\hline Kemah & Miocene & 39.6 & 38.9 & 31 & 14 & 14 & 6.7 & 5.4 & 56.7 & 4.1 & & & & & 87.1 & 4.3 & 4.2 & 15.6 & 6.7 & 5.4 & $c w$ \\
\hline 5538 & & 39.656 & 39.020 & 7 & & & no result & & & & & & & & & & & & & & \\
\hline SS39 & & 39.661 & 39.020 & 12 & 9 & 9 & 188.6 & 8.4 & -57.7 & 6.1 & 179.1 & 4.6 & -33.3 & 6.8 & 137.7 & 4.4 & 5.0 & 20.5 & & & \\
\hline 5540 & & 39.612 & 38.829 & 7 & & & no result & & & & & & & & & & & & & & \\
\hline SS41 & & 39.606 & 38.827 & 5 & 5 & 5 & 183.5 & 4.0 & -54.9 & 3.2 & 136 & 12.2 & -7.55 & 3.3 & 190.2 & 5.6 & 6.3 & 29.7 & & & \\
\hline Kalkar & Miocene & 39.2 & 35.9 & 36 & 31 & 27 & 10.1 & 10.3 & 60.0 & 6.8 & & & & & 23.4 & 5.5 & 3.1 & 9.6 & 10.1 & 10.3 & $\mathrm{cw}$ \\
\hline $\begin{array}{l}\text { Kaleköy+Karaözü Langereis et al. (1990) } \\
\text { LITERATURE REVIEW }\end{array}$ & & 39.223 & 35.943 & 36 & 31 & 27 & 10.1 & 10.3 & 60.0 & 6.8 & 336.1 & 5.9 & 34.3 & 8.4 & 23.4 & 5.5 & 3.1 & 9.6 & & & \\
\hline Cappadocia $(2,3,10,11)$ & Late Miocene-Pliocene & 38.864 & 33.903 & & 80 & 77 & & & & & 353.5 & 3.3 & 50.7 & 3.1 & 33.8 & 2.8 & 2.1 & 5.3 & 6.5 & 3.3 & $\mathrm{ccw}$ \\
\hline Kırşehir - AAB (9) & Upper Cretaceous & 38.910 & 33.810 & & 248 & 242 & 331.3 & 2.8 & 49.8 & 2.7 & & & & & 14.8 & 2.4 & 1.3 & 2.6 & 28.7 & 2.8 & $\mathrm{ccw}$ \\
\hline Kırşehir - KKB (9) & Upper Cretaceous & 39.590 & 33.430 & & 268 & 266 & 352.8 & 2.6 & 56.3 & 2 & & & & & 17.9 & 2.1 & 1.3 & 2.4 & 7.2 & 2.6 & $\mathrm{ccw}$ \\
\hline Kirşehir - AYB (9) & Upper Cretaceous & 39.790 & 34.960 & & 66 & 64 & 18.4 & 6 & 54.1 & 5 & & & & & 13.8 & 5 & 2.3 & 6 & 18.4 & 6 & $\mathrm{cw}$ \\
\hline Kepezdağ (6) & Miocene (16-14 Ma) & 38.300 & 37.600 & & 10 & 10 & & & & & 334.1 & 19.5 & 51 & 18.1 & 9.5 & 16.5 & 4.8 & 19.2 & 25.9 & 19.5 & $\mathrm{ccw}$ \\
\hline Yamadağ (6) & Miocene (18-9 Ma) & 39.000 & 38.100 & & 64 & 61 & & & & & 332 & 6.2 & 50.4 & 5.9 & 12.9 & 5.3 & 2.3 & 6.2 & 28 & 6.2 & $\mathrm{ccw}$ \\
\hline Eastern Taurides $(4,11)$ & Middle Eocene & 38.600 & 36.400 & & 80 & 80 & & & & & 329.8 & 3.8 & 45.3 & 4.3 & 22.3 & 3.4 & 2.1 & 5.2 & 30.2 & 3.8 & $\mathrm{ccw}$ \\
\hline Eastern Taurides Ecemis (11) & Upper Cretaceous & 37.400 & 34.900 & & 158 & 154 & & & & & 318.5 & 3 & 30.4 & 4.7 & 16.1 & 2.9 & 1.6 & 3.4 & 41.5 & 3 & $\mathrm{ccw}$ \\
\hline Pontide orocline E limb (5) & Upper Cretaceous & 41.300 & 35.400 & & 121 & 112 & & & & & 32.1 & 4.1 & 40.5 & 5.1 & 13.7 & 3.7 & 1.8 & 4.2 & 32.1 & 4.1 & $\mathrm{cw}$ \\
\hline Pontide orocline centre (5) & Upper Cretaceous & 41.800 & 33.600 & & 77 & 77 & & & & & 353.6 & 3.4 & 36.9 & 4.6 & 26.7 & 3.2 & 2.1 & 5.3 & 6.4 & 3.4 & $\mathrm{ccw}$ \\
\hline Pontide orocline W limb (5) & Upper Cretaceous & 44.400 & 32.100 & & 448 & 437 & & & & & 334.6 & 1.4 & 44.1 & 1.6 & 28.6 & 1.3 & 1.1 & 1.8 & 25.4 & 1.4 & $\mathrm{ccw}$ \\
\hline Eastern Pontides all $(4-5,12-15)$ & Upper Cretaceous-Eocene & 40.600 & 38.400 & & 161 & 160 & & & & & 359.7 & 2.7 & 42.8 & 3.2 & 22.4 & 2.4 & 1.6 & 3.4 & 0.3 & 2.7 & $\mathrm{ccw}$ \\
\hline & & & & & & & & & & & & & & & & & & & & & \\
\hline & & & & & & & & & & & & & & & & & & & & & \\
\hline
\end{tabular}




\subsection{Rock magnetism}

Thermomagnetic analyses to determine the nature of magnetic carriers were performed on representative samples for each of the 121 sites using a horizontal translation-type Curie balance with cycling applied magnetic field, usually 150 $300 \mathrm{mT}$ (Mullender et al., 1993). Depending on the magnetic intensity of the sample, $30-100 \mathrm{mg}$ of finely crushed rock material per site was measured in a quartz vial. As a rule, eight heating-cooling cycles were applied to detect magnetomineralogical alterations during heating. We used the following temperature scheme (in ${ }^{\circ} \mathrm{C}$ ): $20-150,50-250,150-350$, 250-400, 300-450, 350-525, 420-580, and 500-700.

\subsection{Demagnetization}

Samples were subjected to progressive stepwise demagnetization using either thermal (TH) or alternating field (AF) steps, from room temperature up to a maximum of $680^{\circ} \mathrm{C}$, and a maximum field of $100 \mathrm{mT}$, respectively. To more efficiently separate secondary and primary components by $\mathrm{AF}$ demagnetization, specimens were heated to $150{ }^{\circ} \mathrm{C}$ to remove possible viscous or present-day field overprints caused by weathering and to reduce the coercivities of the secondary overprint in the natural remanent magnetization (NRM; Van Velzen and Zijderveld, 1995). Temperatures ranging 20$680^{\circ} \mathrm{C}$ with increments of $20-50^{\circ} \mathrm{C}$ were applied to thermally demagnetize the samples in a shielded ASC TD48-SC oven. The NRM after each step was measured on a horizontal 2G DC SQUID cryogenic magnetometer (noise level $3 \times 10^{-12} \mathrm{~A} \mathrm{~m}^{-2}$ ). Demagnetization steps ranging 5-100 mT with field steps of 3-10 mT were applied for AF demagnetization and performed on an in-house-developed, robotassisted, and fully automated 2G DC SQUID cryogenic magnetometer (Mullender et al., 2016).

\subsection{Directional interpretation and statistical treatment}

Paleomagnetic interpretations and statistical analyses were carried out using the platform-independent portal paleomagnetism.org (Koymans et al., 2016). All data, interpretations, and statistics of this study are provided in file formats that can be imported into the portal. Stepwise demagnetization of the NRM is displayed in orthogonal vector diagrams (Zijderveld, 1967). Characteristic remanent magnetization (ChRM) directions were interpreted using principal component analysis (PCA) following an eigenvector approach (Kirschvink, 1980). Great circle analysis following McFadden and McElhinny (1988) was performed if components were not entirely resolved upon demagnetization or became viscous or spurious at higher temperatures or coercivities. Mean directions were determined using Fisher (1953) statistics applied on virtual geomagnetic poles (VGPs), and errors in declination $\left(\Delta D_{x}\right)$ and inclination $\left(\Delta I_{x}\right)$ were calculated following Butler (1992). We applied the reliability criteria of Deenen et al. $(2011,2014)$ by determining $A_{95}$ of the VGP distribution and calculate the $n$-dependent values of $A_{95 \min }$ and $A_{95 \max }$ : values plotting within this envelope can be explained by paleosecular variation (PSV), while values outside the envelope may indicate sources of enhanced scatter $\left(A_{95}>A_{95 \max }\right)$ or underrepresentation of PSV $\left(A_{95}<\mathrm{A}_{95 \mathrm{~min}}\right)$, e.g., due to remagnetization. To test the origin of the ChRM, field tests (reversal test, fold test) were performed where possible (Tauxe and Watson, 1994; Tauxe, 2010; Fig. 7). A fixed $45^{\circ}$ cutoff was applied to the VGP distributions on the site and locality level (Johnson et al., 2008; Deenen et al., 2011). Using these tests, we establish whether the locality carries a primary or secondary magnetization. In the discussion section, we assess the reliability and consistency of our paleomagnetic results and evaluate the tectonic implications

\subsection{Compilation of previous paleomagnetic results}

We have compiled published paleomagnetic data from the Taurides, Kırşehir Block, and Pontides previously used to infer rotation patterns in Central Anatolia. This paleomagnetic database is provided in the Supplement and in a paleomagnetism.org compatible format. Literature references are provided in the description of the Supplement. All sites are given in tectonic coordinates (i.e., corrected for bedding tilt) where possible. All paleomagnetic directions were converted to normal polarity. The database was built following selection criteria listed in Li et al. (2017). Because the paleomagnetic community does not normally publish their original data but only the statistical parameters (Dec, Inc, $N, k)$ of the dataset, we have created parametrically sampled datasets for each site to facilitate averaging directions rather than means (see Deenen et al., 2011). Since the average directions in our compilation are based on parametric sampling, they may differ somewhat from the published ones. Locality averages for the segments of the Pontide orocline, the Kırşehir Block, and the Eastern Taurides based on these literature data are provided in Table 1.

\section{Results}

\subsection{Rock magnetism}

Most samples showed decreasing magnetization up to temperatures of $550-580^{\circ} \mathrm{C}$, indicative of (Ti-poor) magnetite. Often, oxidation of pyrite upon thermal demagnetization forms magnetite around $400^{\circ} \mathrm{C}$ (Passier et al., 2001), leading to spurious demagnetization behavior at higher temperatures. Occasionally, the presence of hematite is seen by the removal of the magnetization at temperatures as high as $680^{\circ} \mathrm{C}$. These results are consistent with Curie balance measurements, of which nine representative results are shown in Fig. 4. The following patterns were observed in thermomagnetic curves, which aided our demagnetization strategy, whereby 

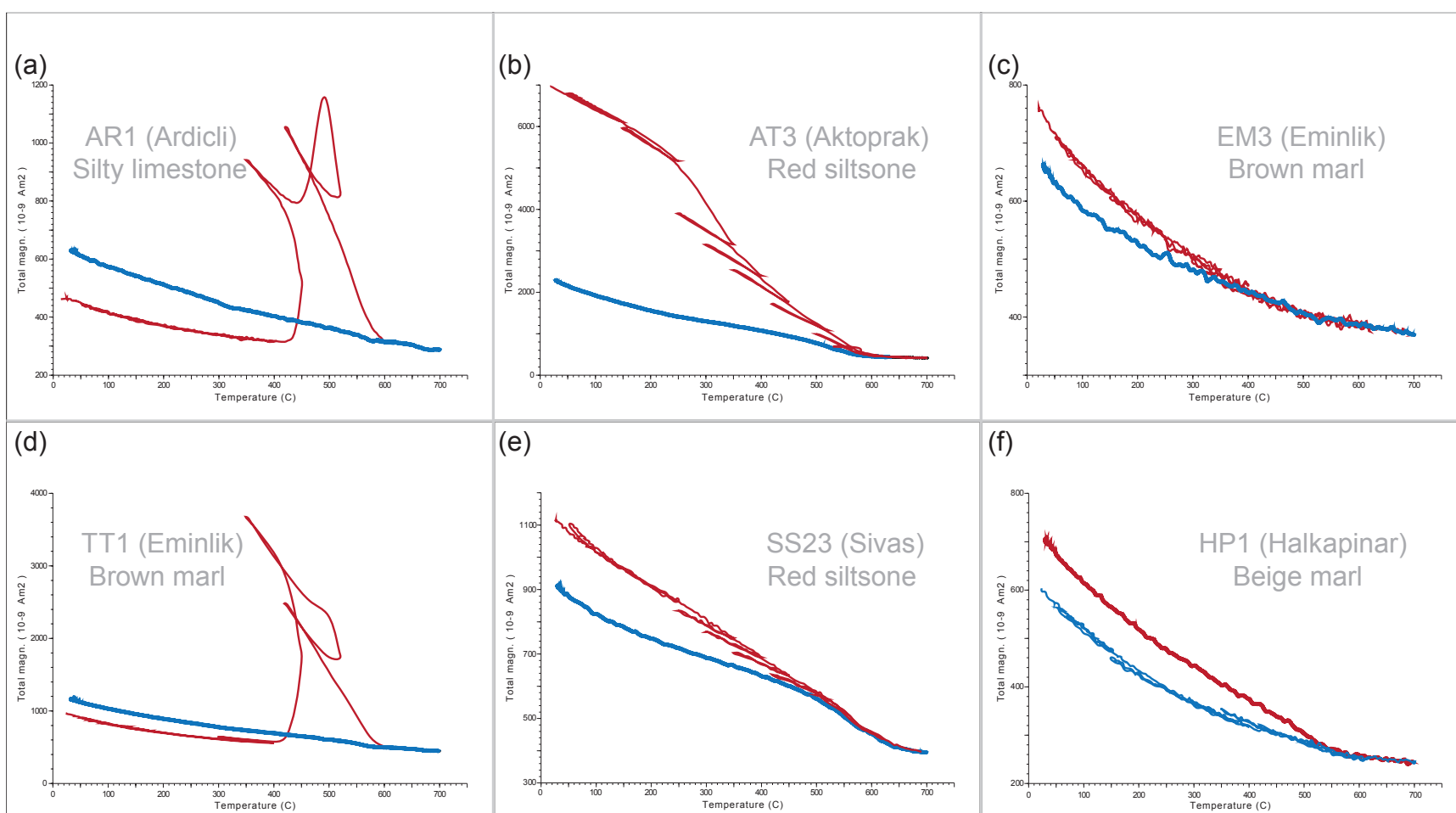

(e)

(f)
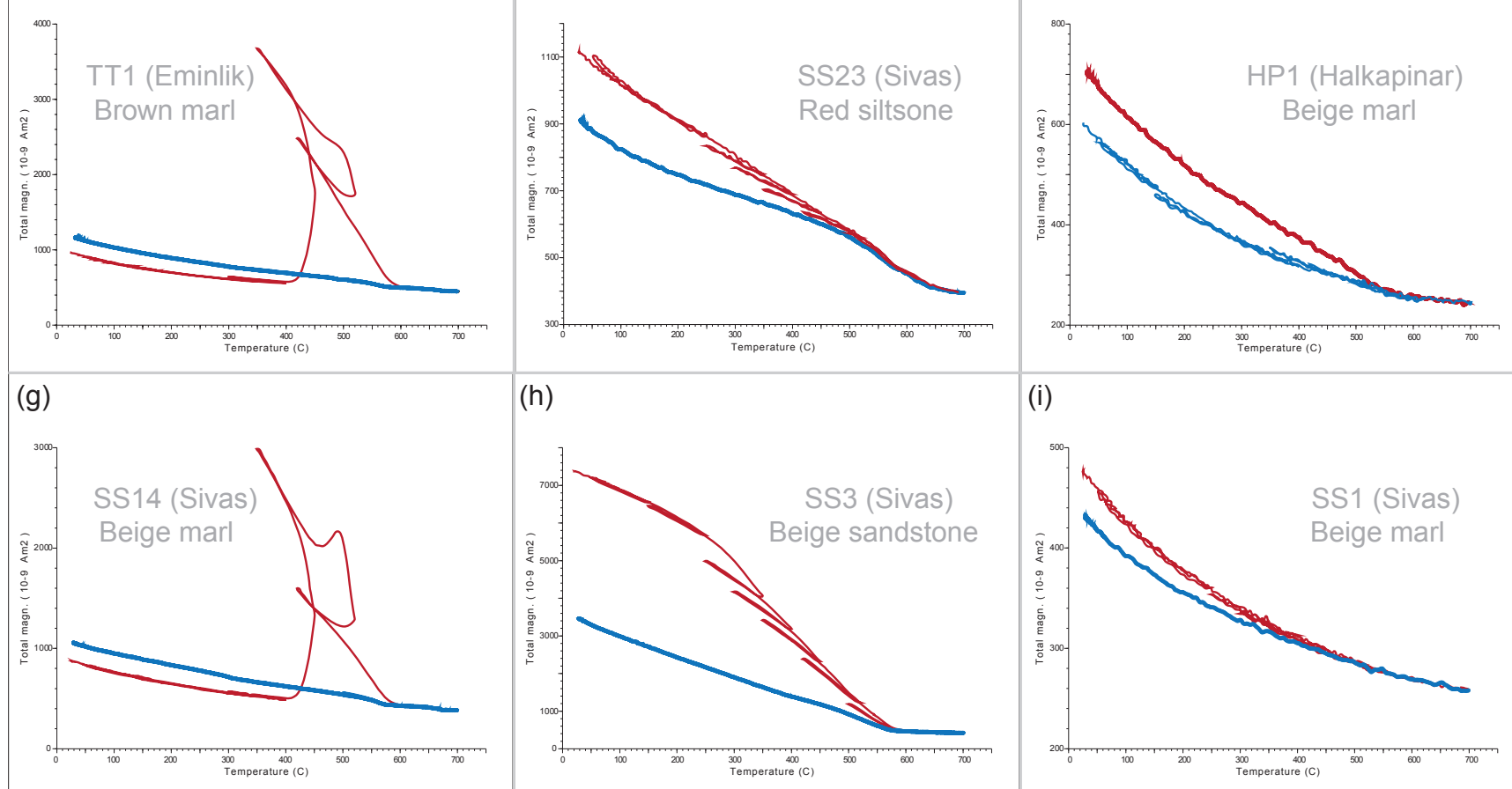

(h)

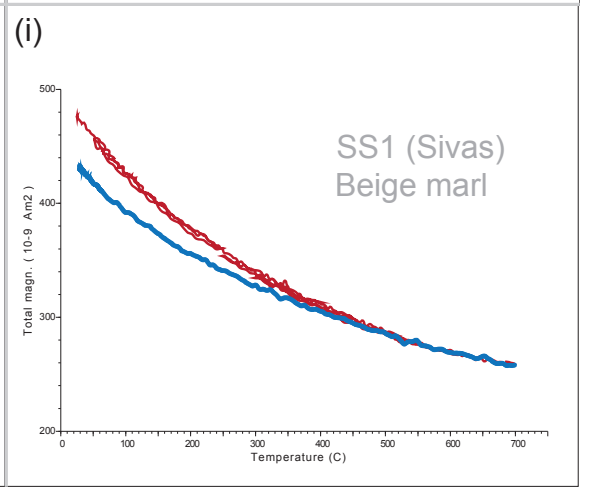

Figure 4. Magnetic carriers identified by their characteristic thermomagnetic curves generated with the stepwise heating protocol (Mullender et al., 1993) for representative samples. Heating is represented by the red line. The final cooling segment is indicated by the blue line. A noisy appearance is indicative of a weak magnetic signal. See text for an explanation of the thermomagnetic behavior.

hematite-bearing samples were preferably $\mathrm{TH}$-demagnetized and pyrite-bearing samples were AF-demagnetized. Nearcontinuous, non-reversible alteration with increasing temperature was recorded by some light-red-colored limestones and continental red siltstones or beige sandstones, showing an inflection around $350^{\circ} \mathrm{C}$ interpreted as inversion of maghemite into hematite (Dankers, 1978) and finally to magnetite at $\sim 580^{\circ} \mathrm{C}$ (Fig. $4 \mathrm{~b}$ and h). The presence of hematite in some red siltstones is evident from a residual magnetic signal up to $680^{\circ} \mathrm{C}$ (Fig. 4e). The cooling curves for these samples are below the heating curves, indicating oxidation of maghemite-magnetite, likely to hematite, which has a lower spontaneous magnetization. The presence of pyrite is evident in a number of marls and limestones, for which the increase in magnetization at $390-420^{\circ} \mathrm{C}$ indicates that pyrite transforms to magnetite, producing an intensity maximum at 480 $500^{\circ} \mathrm{C}$. Above $500^{\circ} \mathrm{C}$, the newly formed magnetite is subsequently demagnetized or oxidized at $580^{\circ} \mathrm{C}$ (Fig. $4 \mathrm{a}$, d, and g). The cooling curves below $400{ }^{\circ} \mathrm{C}$ are higher than the heating curves because of this newly formed magnetite, which causes the spurious demagnetization behavior at temperatures above $400^{\circ} \mathrm{C}$. Pyrite is not always present in the marls, as is evident from marly samples that show a continuous decay until $\sim 580^{\circ} \mathrm{C}$, indicating (T-poor) magnetite only (Fig. 4c, f, and i). Sometimes the amount of magnetite is very small and the Curie curve shows a mostly paramagnetic shape (Fig. 4c and i). Nevertheless, some magnetite must have been present since the cooling curve is lower than 
the heating curve because of demagnetization and oxidation of the magnetite.

\subsection{Demagnetization}

Samples with magnetite-hosted magnetizations showed decreasing magnetization up to $550-580^{\circ} \mathrm{C}$ or fields of $60-$ $100 \mathrm{mT}$. Hematite-bearing samples required higher temperatures up to $680^{\circ} \mathrm{C}$. Generally, low-temperature, lowcoercivity overprints were minor and easily removed at low temperatures $\left(100-150^{\circ} \mathrm{C}\right)$ or low alternating fields $(10-$ $15 \mathrm{mT}$ ); where this was not the case, we used great circles and if possible determined great circle solutions (McFadden and McElhinny, 1988). Many samples and sites yielded no reliable paleomagnetic results and were discarded from further analysis. Below we discuss per locality the reason for discarding them. Typical causes are too-low intensities, alteration upon heating and subsequent erratic magnetization behavior, or a component that, in geographic coordinates, cannot be distinguished from a recent field overprint, in this case a geocentric axial dipole (GAD) direction for the locality. In interpreting the demagnetization diagrams, we did not rely on criteria for the maximum angular deviation (MAD; Kirschvink, 1980) because this cannot be justified from a statistical standpoint and depends on anchoring or not anchoring to the origin (Heslop and Roberts, 2016). In almost all cases, anchoring produces an artificially low uncertainty estimation (MAD) compared to an unanchored fit; this is inherent in the method used in the PCA. In our interpretations, common sense and consistency of the results dictated whether or not to anchor. Although the criteria to anchor or not to anchor have very recently been placed on firm statistical footing by Bayesian model selection (Heslop and Roberts, 2016), this has not been implemented (yet) in the paleomagnetism.org online tool.

In determining the means per locality, we averaged all individual directions of the sites of that locality. We therefore break with paleomagnetic tradition to average the site means per locality, although these are given in Table 1. Site means are unit vectors regardless of the number of samples per site, and therefore site mean cones of confidence $\left(A_{95}\right)$ and dispersion $(K)$ are not propagated. By taking all site directions together, sites with more samples naturally have more weight. Since we use the Deenen et al. $(2014,2011)$ criteria, this approach is warranted because the range of acceptable $A_{95}$ is $N$-dependent, contrary to the traditional criteria (e.g., Van der Voo, 1990; see the discussion and Fig. 3 in Deenen et al., 2011). $A_{95}$ should fall within the $A_{95_{\min }}-A_{95_{\max }}$ envelope, which becomes stricter ("narrower") with increasing $N$. The estimate of dispersion $(K)$ of the distribution, however, is largely independent of $N$ (for $N$ sufficiently large, for example $N>10$ ) and for increasing $N$ becomes an increasingly better estimate for the true dispersion $(\kappa)$ of the distribution.

\subsection{Paleomagnetic results}

Below, we describe the paleomagnetic directions obtained from each of our 21 localities. Results are summarized in Table 1 and locality averages are illustrated in Figs. 2 and 3. All demagnetization diagrams per site are provided in the online Supplement as site.dir files that can be imported into paleomagnetism.org; representative examples for most localities are shown (Fig. 5). Statistical analysis was first performed on a per site basis (Table 1), whereby outliers were omitted (but are listed in Table 1 and in the provided paleomagnetism.org locality.pmag files). Subsequently, individual directions from the 21 localities were grouped and averaged (Figs. 2, 3, and 6; Table 1). Locality averages were calculated using individual sample directions, such that large sites (large number of samples) have a larger statistical weight than smaller ones, following procedures in Deenen et al. $(2011,2014)$. Locality results are shown as equal area projections of ChRM directions and their means before and after tectonic correction (Fig. 6, Table 1). All locality results are provided in the online Supplement and can be visualized and used in paleomagnetism.org.

\subsubsection{Ulukışla Basin}

Within the Ulukışla Basin, we collected $\sim 1200$ samples from 49 sites, creating 13 localities consisting of Upper Cretaceous to upper Miocene rocks (Fig. 2, Table 1). Here, we describe these localities from stratigraphically old to young.

Around Alihoca, in the south of the basin (Fig. 2), we collected four sites in Upper Cretaceous red hemipelagic limestones (AL1, AR2) and from blue limestones (AL3, 4; Alihoca-1 locality). In addition, we collected one site (AL2) from upper Paleocene silty marls (Alihoca-2 locality). An overprint in the red limestones was removed at temperatures of $\sim 200^{\circ} \mathrm{C}$. Demagnetization at higher temperatures up to $\sim 450-500^{\circ} \mathrm{C}$ showed a decay trending towards the origin (Fig. 5a and b), and at temperatures above $500{ }^{\circ} \mathrm{C}$ demagnetization behavior becomes erratic. AF demagnetization leads to great circle trajectories and incomplete demagnetization (Fig. 5c), but subsequent thermal demagnetization leads to a decay trending towards the origin and was used for ChRM direction interpretation (Fig. 5d). We interpret that the ChRM is mainly carried by (pigmentary) hematite. The blue limestones yielded directions in geographic coordinates (AL4) coinciding with the recent field component or erratic demagnetization behavior due to very low intensities (AL3); both sites were discarded. Sites AL1 (reversed) and AR2 (normal) do not give a positive reversal test, and an optimal clustering of their directions at $130 \%$ unfolding (Fig. 7a) provides an indeterminate (but not negative) fold test. Both sites give $A_{95}$ values that are just above $A_{95_{\min }}$, showing that they may be explained by PSV, but only barely. The Paleocene site (AL2) yielded mainly great circle trajectories for AF fields up to $40 \mathrm{mT}$ and displayed gyroremanence at higher coercivities 


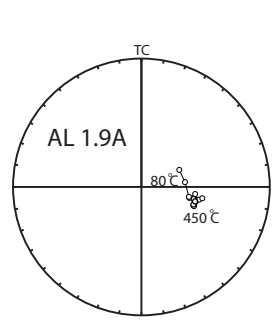

(a)

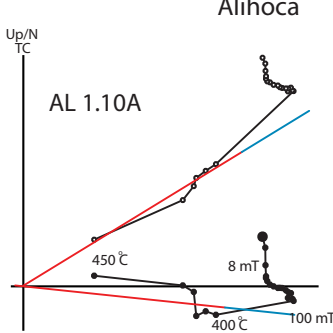

(b)

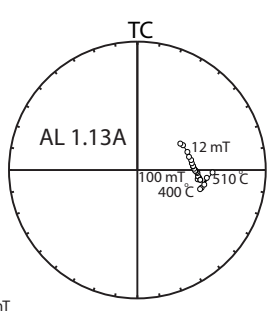

(c)

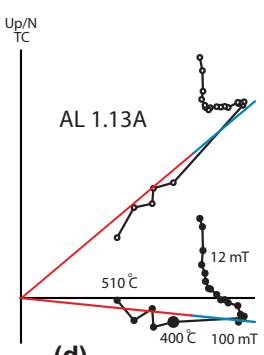

(d)

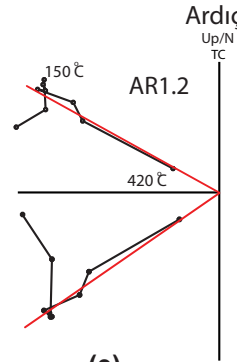

(e)

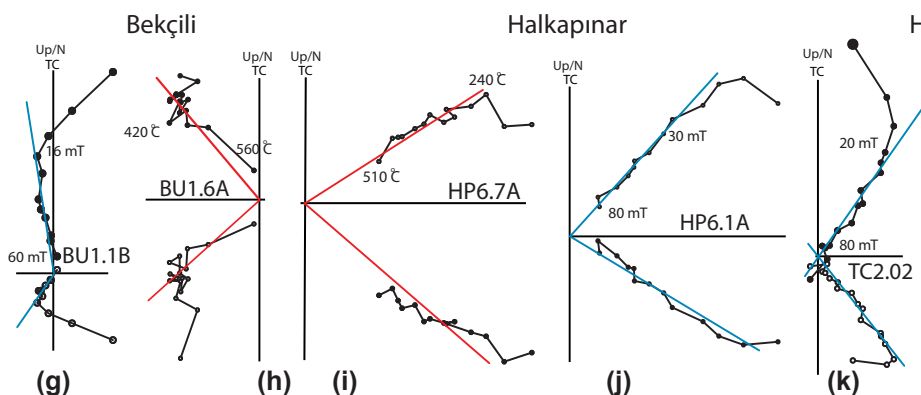

Hasangazi

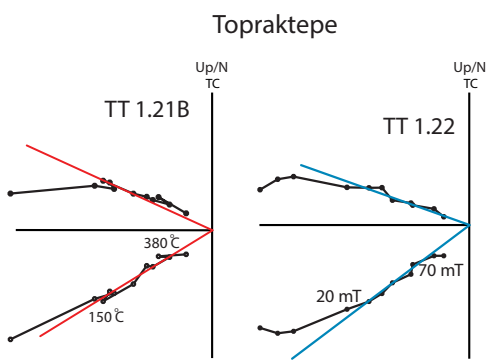

(m)

(n)
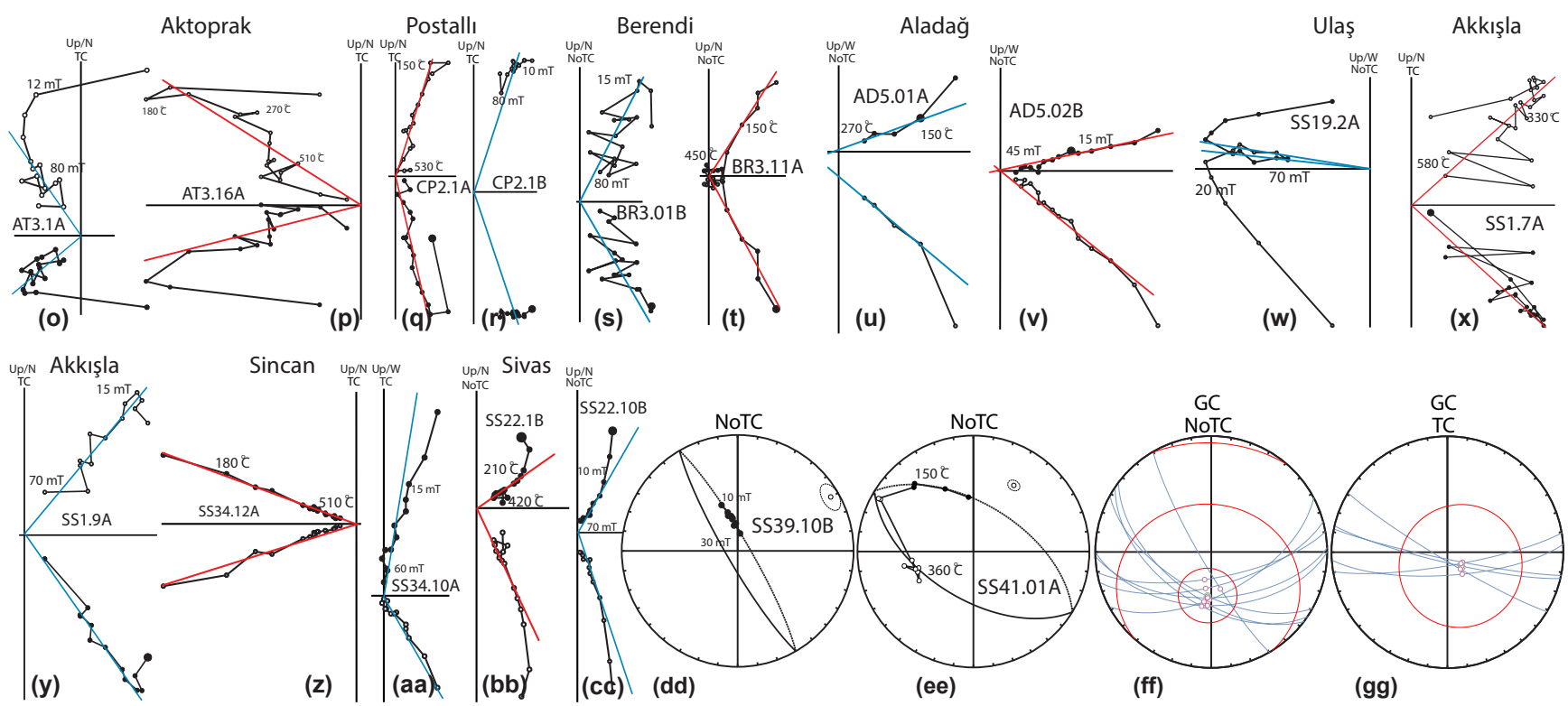

Figure 5. Zijderveld diagrams (Zijderveld, 1967) of representative samples demagnetized using thermal (red lines, TH) and alternating field (blue lines, AF) demagnetization shown in in situ (noTC) or tectonic (TC) coordinates. The solid and open dots represent projections on the horizontal and vertical planes, respectively. Great circle plots (g, h, and jj) use the technique of McFadden and McElhinny (1988). Demagnetization step values are in ${ }^{\circ} \mathrm{C}$ or in $\mathrm{mT}$. See text for further explanation.

(Dankers and Zijderveld, 1981). The set points derived from thermal demagnetization showed a strongly rotated reversed field. The $A_{95}$ of AL2 lies within the $A_{95_{\min -\max }}$ envelope. The Alihoca locality consistently shows large rotations as much as $85^{\circ} \mathrm{ccw}$ (Figs. 2 and $6 \mathrm{a}$ and b)

The Ardlçlı locality was sampled in two sites (AR1, AR3) along a road section along the canyon to Ardiçlı village in the southeast of the Ulukışla Basin (Fig. 2). The lithology is a dark gray sandy-silty limestone of CampanianMaastrichtian age. A recent component was resolved at tem- peratures up to $\sim 200^{\circ} \mathrm{C}$ and fields of $\sim 50 \mathrm{mT}$. In most cases, linear decay towards the origin occurred at temperatures up to $\sim 420^{\circ} \mathrm{C}$ (Fig. 5e), suggesting an iron sulfide as the carrier of the magnetization. AF demagnetization does fully demagnetize the NRM, but at fields of $60-100 \mathrm{mT}$ the direction is indistinguishable from thermal demagnetization (Fig. 5f). The thermal and AF behavior is consistent with the presence of fine-grained pyrrhotite, which has very high coercivities (Dekkers, 1988). A total of 12 (out of 34) samples gave noisy demagnetization data from which no ChRM was 
(a)

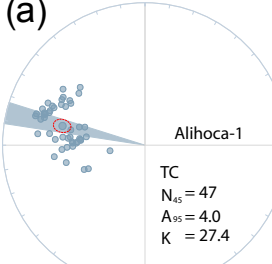

(f)

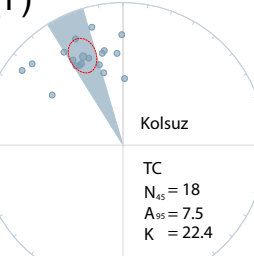

(k)

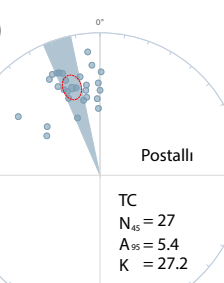

(p)

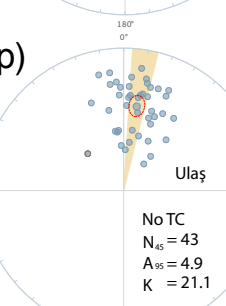

(u)

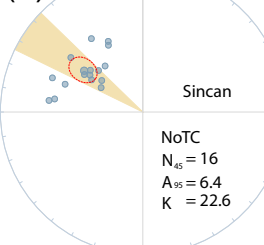

$(\mathrm{zz})$

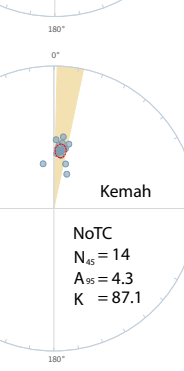

(b)

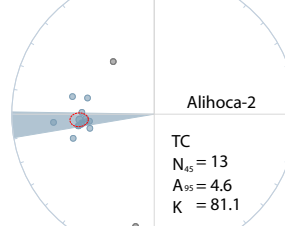

(g)

(I)
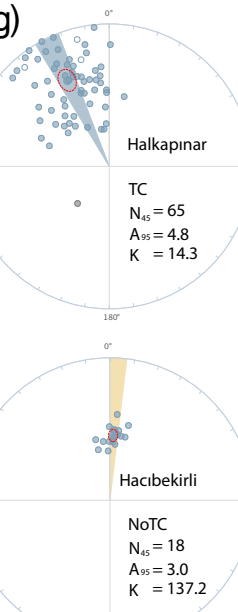

(q)

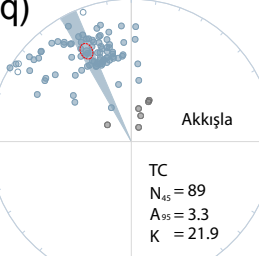

(v)

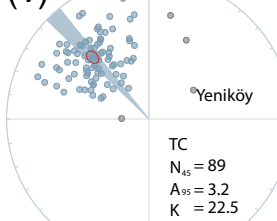

(aa) (c)

Ardıçıı

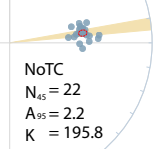

(h)

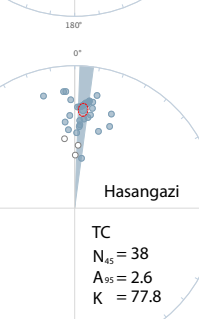

(m)

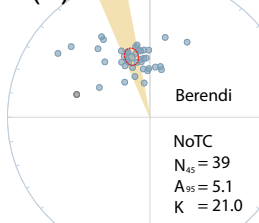

(r)

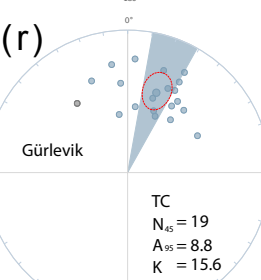

(w)

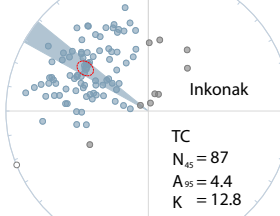

(d)

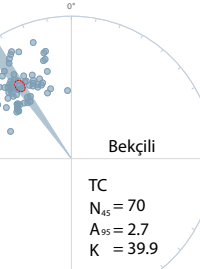

(i)

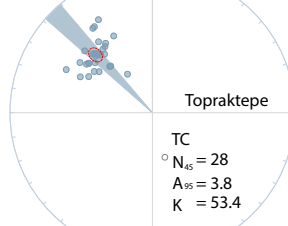

(n)

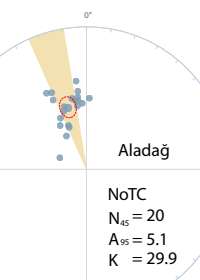

(s)

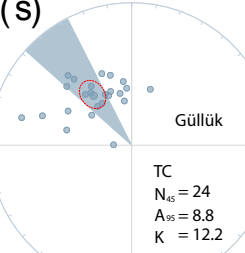

(x)

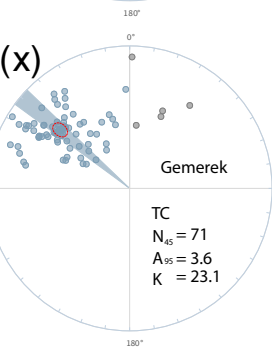

(e)

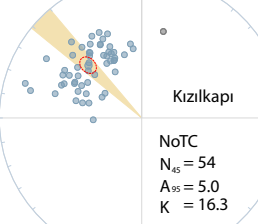

(j)

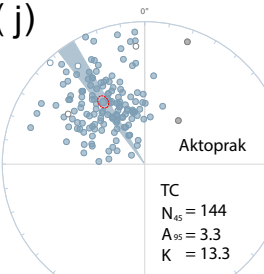

(o)

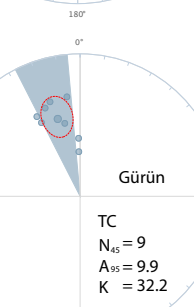

$(\mathrm{t})$

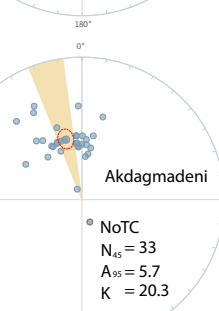

(y)

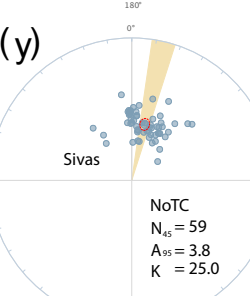

Figure 6. Locality results from sedimentary basins (Ulukışla and Sivas basins, and basins overlying the Tauride fold-and-thrust belt). Equal area projections of ChRM directions and their means with associated error ellipses $\left(\Delta D_{x}, \Delta I_{x}\right)$ according to Deenen et al. (2011), either before (orange; NoTC) or after tectonic correction (blue; TC). Rejected directions (after $45^{\circ}$ cutoff) are displayed in gray, and positive (negative) inclinations are shown as solid (open) circles. All directions have been converted to normal polarity (see also Table 1). 

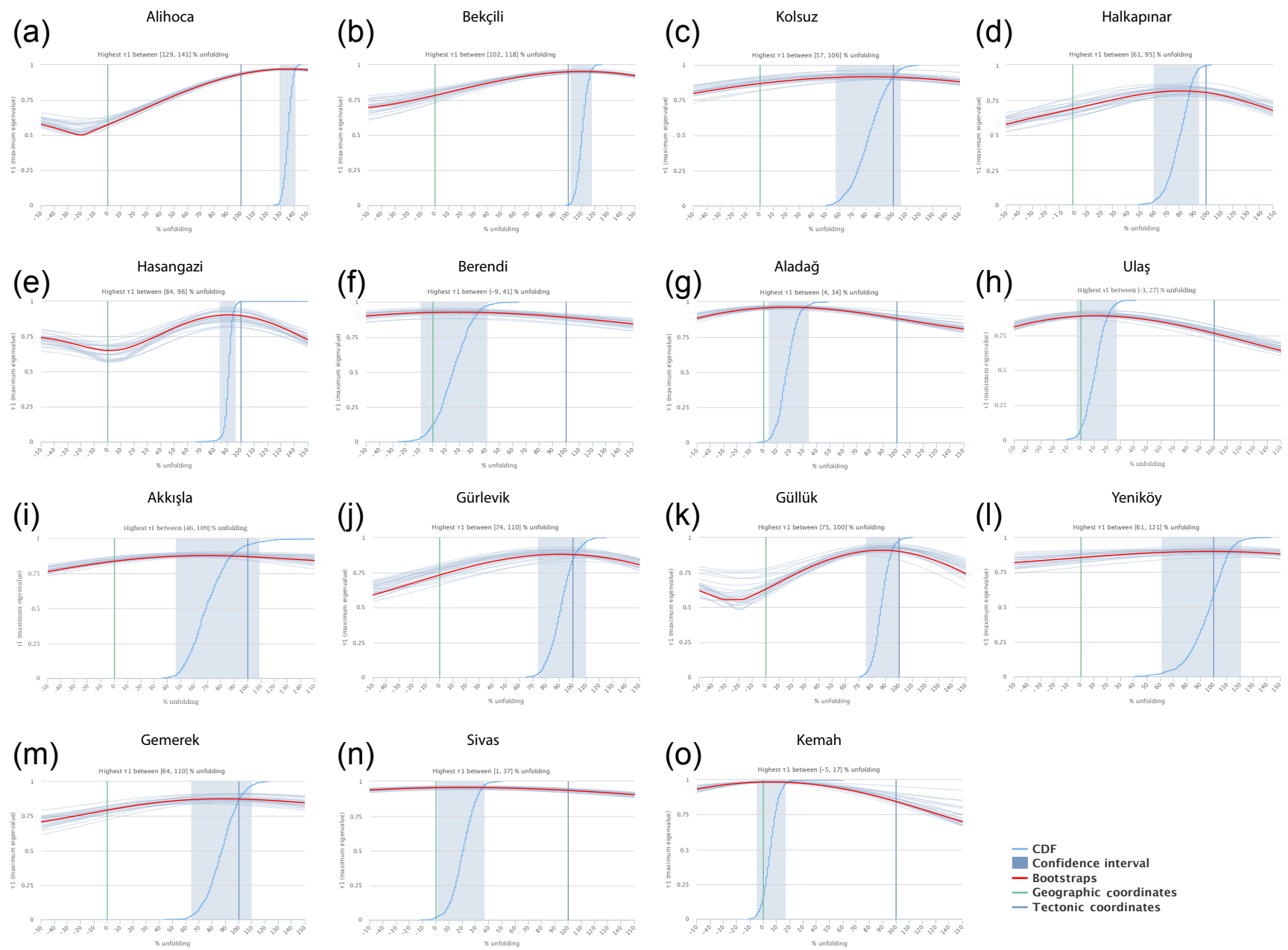

Figure 7. Representative fold tests after Tauxe et al. (2010) for localities from the Ulukışla and Sivas basins.

interpreted. The two sites share the same bedding and a fold test is thus not possible. The direction in tectonic coordinates would suggest a vertical axis rotation of $45.2 \pm 2.8^{\circ} \mathrm{cw}$. We note, however, that $A_{95}$ (2.7) is lower than the $A_{95_{\min }}$ (3.5), indicating undersampling of PSV. This may suggest that the magnetization was acquired in a time period that was too short to fully represent PSV, generally thought to average on a 10000 - to 100000 -year timescale (e.g., Deenen et al., 2011, and references therein). Because both sites were collected from several tens of meters of fine-grained sediments, which likely covers a sufficiently long time interval, such undersampling may indicate remagnetization. We further note that the tilt-corrected inclination of $\sim 30^{\circ}$ is considerably lower than the inclination expected for Eurasia in

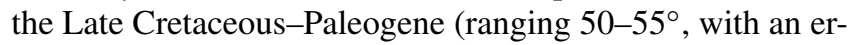
ror of $\pm 3^{\circ}$ ). Admittedly, the lower inclination may result from compaction-induced inclination shallowing (by more than $20^{\circ}$ ), but the $A_{95}$ is too low to represent PSV points to remagnetization (and hence no inclination error), so we consider the inclination of $\sim 45^{\circ}$ in geographic coordinates to be close to the expected inclination for the plate against which the Anatolian collage accreted in the Cretaceous to Paleogene, which would be consistent with a post-tilt remagnetization. In any case, the locality would indicate a major clockwise rotation of $\sim 45^{\circ}$ since the Late Cretaceous-Paleogene if not remagnetized or $\sim 80^{\circ}$ following post-tilt remagnetization (Fig. 6c, Table 1).

The Bekçili locality consists of six sites collected from uppermost Cretaceous to upper Paleocene marls and interbedded turbiditic sandstones (Çamardı Formation) in the northern part of the Ulukışla Basin (Fig. 2) between the villages of Bekçili and Üskül. A recent component is generally removed at $15 \mathrm{mT}$ or $\sim 200-250^{\circ} \mathrm{C}$. Subsequently, the component trending towards the origin between 20 and $60 \mathrm{mT}$ or 250 and $560^{\circ} \mathrm{C}$ is interpreted as the ChRM (Fig. $5 \mathrm{~g}$ and h), likely carried by magnetite. The $A_{95}$ of the mean lies within the $A_{95_{\min } \text { max }}$ envelope. In addition, the locality yields a positive fold test (Fig. 7b). The Bekçili locality therefore provides a well-defined rotation of $35.4 \pm 2.9^{\circ} \mathrm{ccw}$ (Figs. 2 and $6 \mathrm{~d}$, Table 1). 
The Klzılkapı locality is based on five sites sampled in upper Paleocene marls and siltstones in the north of the basin between Kizılkapı and Postallı villages (Fig. 2). A recent component is generally removed at $20 \mathrm{mT}$ or $\sim 220$ $240{ }^{\circ} \mathrm{C}$. A component trending towards the origin between 20 and $50 \mathrm{mT}$ or 275 and $450^{\circ} \mathrm{C}$ is interpreted as the ChRM, likely carried by magnetite. At higher temperatures, the magnetization becomes erratic because of the oxidation of pyrite. Site PC3 provided only erratic demagnetization behavior and was discarded. Site PC1 yielded an inconsistent direction in both geographic and tectonic coordinates $\left(D / I=\sim 52 /-47^{\circ}\right.$ and $357 /-65^{\circ}$, respectively) and was discarded from further analysis. The remaining sites CP1, PC2, and PC4 yield inclinations that are significantly steeper than predicted for the Eurasian reference $\left(\sim 64 \pm 4^{\circ}\right.$ vs. $\sim 50^{\circ}$ ), while in geographic coordinates the inclination is $46.5 \pm 5.7^{\circ}$. We therefore interpret the magnetization as post-tilt, suggesting a post-remagnetization, post-tilt rotation of $45.5 \pm 5.4^{\circ} \mathrm{ccw}$ (Figs. 2 and 6e, Table 1).

The Kolsuz locality consists of two sites collected from Paleocene marine marls interbedded with volcanic rocks in the west of the basin (Fig. 2). A recent component is generally removed at $20 \mathrm{mT}$ and $\sim 180^{\circ} \mathrm{C}$, and decay towards the origin or great circle trends occurs between 20 and $50 \mathrm{mT}$ and 200 and $\sim 450{ }^{\circ} \mathrm{C}$, suggesting magnetite as a carrier. The two sites both yield reversed polarity directions with shallow inclinations of $\sim 30^{\circ}$, both before and after tilt correction, which may be explained by compaction-induced inclination shallowing. A fold test is positive (Fig. 7c). The two sites combined yield an $A_{95}$ value within the $A_{95_{\min -\max }}$ envelope. The locality suggests a rotation of $24.2 \pm 7.8^{\circ} \mathrm{ccw}$ (Figs. 2 and 6f, Table 1).

The Halkapinar locality consists of nine sites collected from Paleocene to middle Eocene siltstones and marls in the southwest of the basin (Fig. 2). Site HP5 showed erratic demagnetization behavior, while site HP4 yielded unrealistic inclinations both in geographic and tectonic coordinates. Site $\mathrm{KG} 1$ provided a direction that in geographic coordinates coincides with the recent component and in tectonic coordinates yielded a very low inclination of $\sim 15^{\circ}$; we interpret the site as a recent overprint and discard it. Site YL1 provides a tightly clustered set of reversed directions decaying towards the origin at low temperatures of up to $200^{\circ} \mathrm{C}$, with an $A_{95}\left(4.3^{\circ}\right)$ lower than $A_{95_{\min }}\left(6.3^{\circ}\right)$. The inclination in geographic coordinates $\left(-53 \pm 6^{\circ}\right)$ coincides with the expected inclination for the sample locality, whereas in tectonic coordinates it is too low $\left(-25 \pm 8^{\circ}\right)$. We discard sites HP4, HP5, $\mathrm{KG} 1$, and YL1 (Table 1). Of the remaining five sites, KG2 and HP2 have normal polarity and HP1, HP3, and HP6 have reversed polarity. A recent component direction was eliminated at temperatures of $\sim 100-150^{\circ} \mathrm{C}$ and fields of 10 $15 \mathrm{mT}$. The ChRM components were interpreted between 300 and $500-600^{\circ} \mathrm{C}$ and $15-80 \mathrm{mT}$ (Fig. 5i and j). The primary carrier of the magnetic signal is magnetite. The fold test shows optimal clustering at $\sim 61-95 \%$ unfolding (Fig. $7 \mathrm{~d}$ ).
The Halkapınar sites come from a sedimentary sequence that shows evidence of syn-folding sedimentation: the lower part of this sequence is tilted steeper to the north than the upper part (Gürer et al., 2016), consistent with the fold test, and we hence interpret the magnetization as primary. The $A_{95}$ value is within the $A_{95_{\min } \text { max }}$ envelope (Deenen et al., 2011). The locality thus demonstrates a well-defined rotation of $25.2 \pm 4.9^{\circ} \mathrm{ccw}$ (Figs. 2 and $6 \mathrm{~g}$, Table 1).

The Eminlik locality was collected at four sites in middle Eocene sandy and silty marls exposed in a syncline in the central part of the basin. A minor viscous component was removed at temperatures up to $\sim 150{ }^{\circ} \mathrm{C}$. The $\mathrm{ChRM}$ of sites was interpreted largely between $\sim 200-450^{\circ} \mathrm{C}$ and $\sim 10$ $30 \mathrm{mT}$. EM1 and EM5 show a declination and inclination indistinguishable from the recent magnetic field and were discarded. In geographic coordinates, sites EM2 and EM4 yielded both normal and reversed antipodal directions with steep inclinations close to the recent field $\left(\sim 56^{\circ}\right)$ and declinations indistinguishable from north and south, respectively. In tectonic coordinates, however, inclinations are unrealistically shallow $\left(8-15^{\circ}\right)$. We interpret these directions to reflect a post-tilt remagnetization of reversed and normal polarity and discard the sites. The four sites of the Eminlik locality hence did not provide a rotation estimate (Table 1).

The Hasangazi locality was collected from six sites sampled in gray sandy limestones and silty marls of Eocene age between Teknecukur and Hasangazi villages (Fig. 2). A minor viscous component was eliminated at temperatures up to $180^{\circ} \mathrm{C}$. In geographic coordinates, three sites from this locality (HG1, GM2, and TC1) are indistinguishable from the recent field (Table 1), while site GM1 yielded erratic demagnetization behavior. These four sites were discarded. For the remaining sites the components from $280-350^{\circ} \mathrm{C}$ or $20-$ $60 \mathrm{mT}$ (TC2 and $320-450^{\circ} \mathrm{C}$ or $20-60 \mathrm{mT}$; HG2) were interpreted as the ChRM or used to construct great circles (Fig. $5 \mathrm{k}$ and 1). Sites HG2 and TC2 defining the Hasangazi locality $(n=33)$ yielded a positive fold test (Fig. 7e). The $A_{95}$ value lies just below the $A 95_{\text {min }}$ value (Table 1 ), which likely results from the use of great circles that seek optimal clustering. We obtain a rotation of $4.9 \pm 2.8^{\circ} \mathrm{cw}$ (Figs. 2 and $6 \mathrm{~h}$, Table 1).

The Topraktepe locality was collected at a single site in middle Eocene silty dark limestones and marls in the central part of the basin (Fig. 2). A component up to $\sim 180^{\circ} \mathrm{C}$ and $20 \mathrm{mT}$ carries a recent component. Decay towards the origin until $\sim 360^{\circ} \mathrm{C}$ is interpreted as a magnetization carried by iron sulfides and erratic behavior above $390-420^{\circ} \mathrm{C}$ is interpreted as the breakdown of pyrite into magnetite (Fig. 4d). The ChRM was interpreted from the linearly decaying component between $\sim 200-350^{\circ} \mathrm{C}$ and $\sim 25-40 \mathrm{mT}$ (Fig. $5 \mathrm{~m}$ and n). The mean yields an $A_{95}$ value within the $A_{95_{\min } \text { max }}$ envelope. The inclination in geographic coordinates is lower $\left(\sim 27^{\circ}\right)$ than in tectonic coordinates $\left(\sim 45^{\circ}\right)$. We interpret the direction as primary, and the locality suggests a rotation of $44.5 \pm 4.1^{\circ} \mathrm{ccw}$ (Figs. 2 and 6i, Table 1). 
The Aktoprak locality contains four sites sampled in Chattian (upper Oligocene) continental brown and red silt and sandstones exposed in the Aktoprak syncline in the southwest of the basin. Curie balance measurements (Fig. 4b) identify magnetite as the main magnetic carrier. Site AT1 yielded erratic demagnetization behavior and site AT4 yielded an average direction indistinguishable from a recent component in geographic coordinates (Table 1). Site AT2 did not yield components linearly decaying towards the origin, while great circles do not show a common intersection. Hence, these three sites were discarded. Site AT3 provided a component trending towards the origin or defining great circle trajectories between 200 and $570^{\circ} \mathrm{C}$ and $20-60 \mathrm{mT}$ (Fig. 5o and p). This site suggests a rotation of $24.5 \pm 10.1^{\circ}$. Meijers et al. (2016) reported paleomagnetic data from the same stratigraphy based on a much larger dataset of $n>120$ directions that is similar to our result from AT3. Combining these results, whereby we parametrically sampled the Meijers et al. (2016) dataset, yields a dataset with an $A_{95}$ value within the $A_{95_{\text {min-max }}}$ envelope, with a mean direction suggesting a rotation of $33.7 \pm 3.8^{\circ} \mathrm{ccw}$ (Figs. 2 and $6 \mathrm{j}$, Table 1 ).

The Postall locality is based on two sites (CP2 and CP3) sampled in red continental sandstones and siltstones and a light-colored tuffaceous sandstone, respectively. Both sites are of (possibly upper) Miocene age and are located in the northern part of the basin, north of Postallı village and dam (Fig. 2). In both sites a recent overprint is removed at temperatures of $\sim 180^{\circ} \mathrm{C}$. The main magnetic carrier of samples in site CP2 seems to be magnetite since the component decaying to the origin and interpreted as ChRM lies between $180^{\circ} \mathrm{C}$ and $500-580^{\circ} \mathrm{C}$ (Fig. 5q). However, AF demagnetization shows a small or virtually no decrease in the NRM, which suggests a highly coercive magnetic mineral. Therefore, the most likely carrier that explains both the thermal and AF behavior is pigmentary hematite. Although AF demagnetization did not lead to full demagnetization, components clustering or slightly decaying towards the origin between 25 and $60 \mathrm{mT}$ were interpreted as the ChRM (Fig. 5r) and are consistent with the thermal demagnetizations. Site CP2 contains reversed directions. In geographic coordinates, the inclination is steep $\left(68.6 \pm 9.0^{\circ}\right)$ and becomes shallower $\left(43.3 \pm 12.0^{\circ}\right)$ in tectonic coordinates. Site CP3 hosts a component that was interpreted as ChRM between $\sim 210-430^{\circ} \mathrm{C}$ and $\sim 25-60 \mathrm{mT}$, likely carried by magnetite. This site contains both normal and reversed polarities, but we have insufficient samples for a meaningful reversal test. The fold test is indeterminate (maximal clustering between $\sim 50$ and $150 \%$ unfolding). $A_{95}$ falls within the $A_{95_{\min } \max }$ envelope. The locality suggests a vertical axis rotation of $17.7 \pm 5.4^{\circ} \mathrm{ccw}$ (Figs. 2 and 6k, Table 1).

The Burç locality contains one site sampled in (possibly upper) Miocene lacustrine sandstones and silts in the northeast of the basin, south of Çamardı (Fig. 2). This site only showed erratic demagnetization behavior, from which no consistent ChRM component was interpreted. Hence, this locality was discarded from further analysis (Table 1).

The Hacıbekirli locality contains one site sampled in upper Miocene terrestrial sandstones and silts in the southwestern part of the basin (Fig. 2). A recent overprint is removed at temperatures of $\sim 150^{\circ} \mathrm{C}$. Components decaying towards the origin between 10 and $30 \mathrm{mT}$ and $150-350{ }^{\circ} \mathrm{C}$ were interpreted as the ChRM. The site yields a reversed magnetization with a tight clustering of interpreted ChRM directions $\left(A_{95}=3.0<A_{95_{\min }}=3.8\right)$, indicating remagnetization. This is supported by the direction in geographic coordinates $\left(\sim 182 /-53^{\circ}\right)$ with an inclination close to the inclination of the recent field, whereas in tectonic coordinates a direction of $165 /-34^{\circ}$ yields a much lower inclination, which would suggest major inclination shallowing (Table 1). In absence of positive field tests, we refrain from interpreting this direction as primary even though the rotation in tectonic coordinates $\left(15^{\circ} \mathrm{ccw}\right)$ would be similar to that from Postalli $\left(18^{\circ} \mathrm{ccw}\right.$; Figs. 2 and 61, Table 1).

Finally, we calculated an average paleomagnetic direction for the upper Miocene to Pliocene volcanic rocks of Cappadocia overlying the AAB Block by combining lava sites previously published by Çinku et al. (2016), Piper et al. (2002a, b, 2013), and Platzman et al. (1998). These yield a mean $(n=77)$ with an $A_{95}(2.8)$ within the $A_{95_{\text {min-max }}}$ envelope $(2.1,5.3)$. These data suggest a vertical axis rotation of $6.5 \pm 3.3^{\circ} \mathrm{ccw}$ (Fig. 1; Table 1).

\subsubsection{Tauride fold-and-thrust belt and overlying basins}

A total of 115 samples from three localities (Berendi, Aladağ, Gürün) consisting of 11 sites were sampled in the Eocene to Miocene stratigraphy of the sediments overlying the Taurides fold-and-thrust belt (Figs. 2 and 3; Table 1). In addition, one locality (Sariz) with 4 sites and 63 samples was sampled from folded and thrusted Late Cretaceous-Eocene limestones within the Eastern Tauride fold-and-thrust belt. The maps (Figs. 2 and 3) show the average declination of each locality with its associated $\Delta D_{x}$, whereby all directions were calculated into normal polarity.

The Berendi locality is based on six sites sampled from shallow marine nodular limestones overlying the Tauride fold-and-thrust belt to southwest of the Ulukışla Basin (Fig. 2). We obtained calcareous nannofossils from this locality (see the Supplement) showing a Thanetian (late Paleocene) to Ypresian (early Eocene) age. Site BR5 gives a direction indistinguishable from a recent component, while site BR6 yielded erratic demagnetization behavior; both sites were discarded. From sites BR1-4, a low-temperature but consistent component with reversed polarity was removed between 100 and $250-400{ }^{\circ} \mathrm{C}$ or between 15 and $50-80 \mathrm{mT}$ and was interpreted as the ChRM (Fig. 5s and t) or defined by great circles. A fold test on sites BR1-4 is clearly negative (Fig. 7f), implying a post-folding magnetization. The remagnetized direction in geographic coordinates has a dec- 
lination of $343.1 \pm 6.2^{\circ}$, suggesting a post-folding rotation of $16.9 \pm 6.2^{\circ} \mathrm{ccw}$ (Figs. 2 and $6 \mathrm{~m}$, Table 1 ).

The Alada $\breve{g}$ locality is based on four sites sampled in folded Oligocene continental red sandstones and silts of the Karsantı Basin overlying the Taurides (Ünlügenç and Akıncı, 2015) near Aladağ village east of the EFZ (Fig. 2). The lower Miocene of the Adana Basin (Figs. 1 and 2) unconformably overlying the Karsantı Basin is not folded. Sites AD1 and AD3 did not result in paleomagnetically meaningful results and were discarded. The magnetization of sites AD4 and AD5 is primarily carried by iron sulfides, most likely pyrrhotite, because the ChRM is generally interpreted between 10 and $70 \mathrm{mT}$ and between low temperatures of 150 and $300^{\circ} \mathrm{C}$ (Fig. 5u and v). Sites AD4 and AD5 yield a negative fold test (Fig. 7g), showing that they carry a post-tilt magnetization acquired sometime after the Oligocene. This is further suggested by the shallow inclinations upon tectonic correction $\left(\sim 30^{\circ}\right.$ compared to $\sim 50^{\circ}$ in geographic coordinates). The combination of these two sites yields a declination in geographic coordinates of $343.4 \pm 7.3^{\circ}$, suggesting a ccw rotation of $16.6 \pm 7.3$ (Figs. 2 and 6n, Table 1) with an ill-defined but post-folding age.

The Sarlz locality consists of four sites, one in Upper Cretaceous and three in Eocene limestones sampled in the Eastern Tauride fold-and-thrust belt to the north of Pınarbaş1 (Fig. 3). In all sites, a recent component is removed at temperatures up to $180^{\circ} \mathrm{C}$ or up to $\sim 25 \mathrm{mT}$, followed by erratic demagnetization behavior. The Sarız locality therefore yielded no reliable directions and was discarded (Table 1).

The Gürün locality was sampled at one site in Miocene mudstones overlying the Eastern Taurides (Fig. 3). A recent component was removed at temperatures of $180^{\circ} \mathrm{C}$. A component trending towards the origin was isolated between $\sim 200$ and $350-450{ }^{\circ} \mathrm{C}$ and was interpreted as the ChRM, whereas AF demagnetization did not yield paleomagnetically meaningful interpretations. In tectonic coordinates, all interpreted samples show a reverse polarity, which results in an average declination of $163.9 \pm 10.9^{\circ}$ after tectonic correction, constraining a rotation of $16.1 \pm 10.9^{\circ} \mathrm{ccw}$ (Figs. 3 and 6o, Table 1). No field tests can be applied to this site (SS10) and we cannot firmly conclude that this site carries a primary magnetization. In geographic coordinates, however, the declination is $146.9 \pm 12^{\circ}$ (Table 1 ), suggesting a ccw rotation of $\sim 33^{\circ}$.

\subsubsection{Sivas Basin}

Within the Sivas Basin, we collected 900 samples from a total of 51 sites defining 12 localities consisting of Paleocene to upper Miocene rocks (Fig. 3, Table 1). Additionally, several published magnetostratigraphic sites from the western part of the basin were reinterpreted (Krijgsman et al., 1996; Langereis et al., 1990). One locality of three sites was sampled on the Kirşehir Block, northwest of the basin.
The Ulas locality is comprised of nine sites from Paleocene-Eocene marls around Ulaş in the central-western part of the region, $\sim 30 \mathrm{~km}$ south of Sivas city (Fig. 3). Most sites of this locality provided either a low-temperature recent component or no results, and we discarded sites SS11, SS18, SS21 SS30, and SS31. The remaining sites SS17, SS19, SS20, and SS29 show in most cases a recent component that is easily removed at $15 \mathrm{mT}$ or $180^{\circ} \mathrm{C}$. ChRM components were interpreted between $10-70 \mathrm{mT}$ and $250-580^{\circ} \mathrm{C}$ (Fig. 5w) and yielded well-defined reversed directions that are very similar in geographic coordinates (Table 1). The fold test of these sites is clearly negative (Fig. 7h), and the magnetization has been acquired after folding. The declination in geographic coordinates $\left(8.8 \pm 5.3^{\circ}\right.$; Figs. 3 and 6 , Table 1$)$ shows a minor $\mathrm{cw}$ rotation since remagnetization.

The Akklşla locality is comprised of eight sites of Eocene age in the southwest of the basin, unconformably overlying Afyon Zone metamorphic rocks east of Akkışla (Fig. 3). All sites were sampled from marls. Two sites (SS1, SS25) have a reversed and six have a normal polarity. Site SS4 gave a direction indistinguishable from a recent component in geographic coordinates and was discarded. In the remaining seven sites a recent component overprint is removed at $\sim 180^{\circ} \mathrm{C}$ or $10-15 \mathrm{mT}$. Components trending towards the origin were interpreted as the ChRM between a range of $\sim 12-60 \mathrm{mT}$ and $180-500^{\circ} \mathrm{C}$ (Fig. 5x and y) and are likely carried by magnetite. The $A_{95}$ of the mean lies within the $A_{95_{\text {min-max }}}$ envelope. The remaining sites yield a positive fold test (Fig. 7i) and the locality mean yields a declination, suggesting a rotation of $26.4 \pm 3.4^{\circ} \mathrm{ccw}$ (Figs. 3 and 6q, Table 1).

The Gürlevik locality was sampled at five sites from Eocene marls north of Gürlevik mountain, between Sincan and Zara in the central southern part of the basin (Fig. 3). Sites SS36, SS43, and SS45 gave no results and were discarded. The magnetization of the remaining sites SS3 and SS44 is primarily carried by magnetite, with the ChRM interpreted generally between $150-370^{\circ} \mathrm{C}$ and $20-65 \mathrm{mT}$. The two sites SS33 and SS44 give a positive fold test (Fig. 7j) and have an $A_{95}$ value within the $A_{95_{\text {min-max }}}$ envelope. The declination shows a rotation of $19.8 \pm 9.5^{\circ} \mathrm{cw}$ in tectonic coordinates (Figs. 3 and 6r, Table 1).

The Güllük locality was sampled at five sites from upper Eocene to Oligocene red sandstones and siltstones in the central part and north of the study area and on the northern flank of Tecer mountain (Fig. 3). The magnetization of these sites is primarily carried by magnetite, with the ChRM interpreted generally between $100-300{ }^{\circ} \mathrm{C}$ and $10-60 \mathrm{mT}$. The five sites provided generally high magnetic intensities with either components linearly decaying towards the origin or, in most cases, well-defined great circles. Those great circles define well-clustered intersections from which sample directions were estimated. Each of the five sites yielded a welldefined average paleomagnetic direction, but these five directions are strongly scattered. This may either reflect strong 
local rotations, which is unlikely given the absence of minibasins, or major faults within this locality. More likely, some of these sites may have been remagnetized by lightning, which would be consistent with their high intensities. Sites SS32 and SS52 give anomalously low inclinations $<15^{\circ}$ and site SS53 gives declination, suggesting a rotation of almost $100^{\circ}$ derived from great circle analyses only. Sites SS51 and SS54, on the other hand, give a positive fold test (Fig. 7k). These two sites suggest a rotation of $37.6 \pm 10.7^{\circ} \mathrm{ccw}$ in tectonic coordinates (Figs. 3 and 6s, Table 1).

The Akdağmadeni locality consists of three sites sampled in Eocene marls and red continental deposits overlying the easternmost part of the Kirşehir Block, northwest of the Sivas Basin (Fig. 3). A recent component overprint is generally removed at fields of $15 \mathrm{mT}$ and temperatures of $150^{\circ} \mathrm{C}$. The primary carrier of the magnetization is magnetite. The sites are characterized by low intensities and unstable demagnetization behavior. Site SS16 only gave recent directions and was discarded. Site SS14 provides mostly erratic directions, but a few samples with reversed polarity yielded an interpretable result for which the ChRM was interpreted between $20-45 \mathrm{mT}$ and $240-370^{\circ} \mathrm{C}$. The interpreted directions and great circles suggest an unrealistically low inclination upon tectonic correction $\left(-27^{\circ}\right)$ compared to in geographic coordinates $\left(\sim 54^{\circ}\right)$. We hence interpret this site to represent a post-tilt magnetization that yields a rotation of $\sim 20^{\circ} \mathrm{ccw}$ in geographic coordinates. Similarly, site SS15 provided some reversed directions, but mostly great circles that yielded no consistent intersection and the site was discarded from further analysis. A fold test of sites SS14 and SS15 was not possible. We note that the inclination of the sites in geographic coordinates is close to the one expected based on the European APWP, whereas in tectonic coordinates, the inclination is very shallow $\left(22-35^{\circ}\right)$, which may indicate a post-tilt magnetization. When combined, the $A_{95}$ of the mean lies within the $A_{95_{\min } \text { max }}$ envelope. In tectonic coordinates, the locality yields a declination, suggesting $\sim 10^{\circ} \mathrm{ccw}$ rotation; in geographic coordinates, the declination would suggest a post-tilt $15^{\circ} \mathrm{ccw}$ rotation (Figs. 3 and 6t, Table 1).

The Sincan locality is based on one site collected in the corridor of red Oligocene siltstones and sandstones north of Kangal and Divriği (Fig. 3). The primary carrier in this site (SS34) is magnetite. A recent component was eliminated at temperatures of $\sim 180^{\circ} \mathrm{C}$ and fields of $10-15 \mathrm{mT}$ (Fig. $5 \mathrm{z}$ and aa). The ChRM was interpreted between temperatures of 200 and $580{ }^{\circ} \mathrm{C}$ and fields of $20-60 \mathrm{mT}$. The directions obtained from well-defined components trending towards the origin yields a declination of $\sim 304.2 \pm 9.0^{\circ}$ and an inclination of $47.8 \pm 9.3^{\circ}$ in geographic coordinates and in tectonic coordinates a declination of $277.5 \pm 6.6^{\circ}$ and a shallow inclination of $25.7 \pm 11.0^{\circ}$. This shallow inclination may indicate that this locality acquired its magnetization after folding. We conservatively estimate a post-folding rotation of $55.8 \pm 9.0^{\circ} \mathrm{ccw}$ (Figs. 3 and $6 \mathrm{u}$, Table 1).
The Yeniköy locality consists of six sites sampled in Oligocene continental redbeds (fluvial and lacustrine siltstones and sandstones) in the southwestern part of the greater Sivas Basin, approximately $20 \mathrm{~km}$ south of Şarkışla (Fig. 3). In addition, samples from 102 levels were collected from an $800 \mathrm{~m}$ long section of redbeds in the Yeniköy locality by Krijgsman et al. (1996). We have reinterpreted their data for rotation analysis. Almost all new sites of this locality gave a direction in geographic coordinates that is close to a recent component. Samples from the remaining site SS58 yielded a ChRM likely carried by hematite considering the temperature needed to fully remove the NRM, in accordance with the lithology (redbeds). The $A_{95}$ of the mean lies within the $A_{95_{\min -\max }}$ envelope. The combined Yeniköy section and SS58 contain both normal and reversed directions. These yielded a positive reversal test and a positive fold test (Fig. 7l). The locality provides a rotation of $42.4 \pm 3.2^{\circ} \mathrm{ccw}$ in tectonic coordinates (Figs. 3 and 6v, Table 1).

The Inkonak locality consists of an upper Oligocene series of fluvial and lacustrine sediments sampled by Krijgsman et al. (1996) for magnetostratigraphic purposes. It was sampled $\sim 50 \mathrm{~km}$ south of Sivas (Fig. 3). The section is $313 \mathrm{~m}$ thick and consists of a regular alternation of clays, limestones, and sandy deposits. We reinterpreted their demagnetization diagrams for tectonic purposes. A recent component was removed at $\sim 100^{\circ} \mathrm{C}$, and the $\mathrm{ChRM}$ was eliminated between 240 and $700{ }^{\circ} \mathrm{C}$. The section yielded both normal and reversed polarity directions. Although the reversal test was not positive in tectonic coordinates owing to an $8^{\circ}$ difference in inclination, the declinations of both groups are identical. There was insufficient variation in the bedding for a meaningful fold test. Combining the normal and reversed directions, a mean ChRM was obtained with an inclination of $45.9 \pm 5.4^{\circ}$ and a declination of $304.0 \pm 5.0^{\circ}$, which suggests a rotation of $56.0 \pm 5.0^{\circ} \mathrm{ccw}$ in tectonic coordinates (Figs. 3 and $6 \mathrm{w}$, Table 1).

The Gemerek locality was sampled in the western part of the basin (Fig. 3) and analyzed by Krijgsman et al. (1996) for magnetostratigraphic purposes and was collected from a continuous stratigraphic section of $200 \mathrm{~m}$ consisting of middle Miocene $(\sim 15 \mathrm{Ma})$ fluvial and lacustrine sediments. We have reanalyzed their data. The samples show a recent component, which was removed at $100-240{ }^{\circ} \mathrm{C}$. The ChRM component was interpreted at temperatures up to $700^{\circ} \mathrm{C}$. The Gemerek locality contains both normal and reversed intervals generally yielding well-defined components trending towards the origin. The normal and reversed directions yield a positive reversal test and a positive fold test (Fig. $7 \mathrm{~m}$ ). The $A_{95}$ of the mean lies within the $A_{95_{\min } \text { max }}$ envelope. We therefore consider the magnetization as primary and interpret a rotation of $49.9 \pm 3.8^{\circ} \mathrm{ccw}$ for this locality (Figs. 3 and $6 \mathrm{x}$, Table 1).

The Bünyan locality consists of one site collected from white lacustrine marls of Miocene age in the west of the basin (Fig. 3). The samples of this site (SS24) only showed a recent 
overprint, and the locality was discarded from further analysis (Table 1).

The Sivas locality was sampled along road cuts on both sides of the main road to Sivas between Kovalı and Güllüce (Fig. 3). All four sites of the locality were sampled from Miocene continental redbeds made of sandstones and silts. Site SS12 yields five reversed directions based on hightemperature components trending towards the origin. In addition, the site yields 20 near-parallel great circles, causing the great circle solutions plus the five set points to create a very highly clustered average that we feel is not substantiated by the quality of the demagnetization diagrams. Hence, we only use the five directly obtained ChRM directions for our average. SS13 yielded well-defined great circles, also yielding a well-defined intersection that we interpret as the ChRM. Site SS22 showed a recent overprint removed at temperatures of $\sim 180^{\circ} \mathrm{C}$ and fields of $5 \mathrm{mT}$. A normal component interpreted as ChRM was found between $300-600^{\circ} \mathrm{C}$ and 8-40 mT (Fig. 5bb and cc). The resulting direction yielded in geographic coordinates an inclination $\left(59.1 \pm 3.7^{\circ}\right)$ close to the one expected for the locality, but a very shallow one $\left(26.5 \pm 5.5^{\circ}\right)$ in tectonic coordinates, suggesting a post-tilt remagnetization. Site SS23 yielded two directly interpreted ChRM directions and a set of great circles with well-defined solutions providing the site average. The four sites yield an indeterminate fold test, but the test is strongly influenced by the five directions of site SS12, which have strongly deviating declinations. Performing the fold test only on SS13, SS22, and SS23 yields a negative fold test (Fig. 7n), suggesting post-folding remagnetization. Moreover, the inclinations $\left(53-59^{\circ}\right)$ of the three sites in geographic coordinates all coincide with the expected one, but are significantly shallower in tectonic coordinates $\left(27-44^{\circ}\right)$. We thus suspect a remagnetization after (most of) the folding and interpret a postremagnetization rotation of $16.3 \pm 4.8^{\circ} \mathrm{cw}$ (Figs. 3 and 6y, Table 1).

The Zara locality consists of three sites sampled along road sections around Bulucan $\sim 20 \mathrm{~km}$ south of Zara (Fig. 3). Site SS37 was collected from shallow marine marls and sandstones and yielded a low-temperature, low-coercivity component coinciding with a recent overprint and was discarded. Sites SS35 and SS42 were sampled in Miocene siltstones and sandstones. Site SS35 yielded only recent overprints that passed the origin, but no single reliable set point (ChRM) could be determined. Similarly, site SS42 yielded only great circles with no clear intersection and was discarded (Table 1).

The Kemah locality consists of four Miocene sites sampled in sandstones and siltstones north of Kemah in the far east of the study region. Magnetite was identified as the primary magnetic carrier. A recent component was removed at 100 $150^{\circ} \mathrm{C}$ and fields of $20 \mathrm{mT}$. Sites SS38 and SS40 yielded strong recent overprints that determined great circle trajectories with no clear intersection; both were discarded. Sites SS39 and SS41 yielded strong recent overprints, but these did not converge towards the origin and defined only great circles but no ChRM directions (Fig. 5ee and ff), whereby the demagnetization diagram suggested that the polarity of the nonrecent component was reversed. The great circles determined from each of these sites showed a clear intersection (Fig. 5 gg and hh), which we used to determine the ChRM directions of each site following the approach of McFadden and McElhinny (1988). The thus determined directions yielded a clearly negative fold test (Fig. 7o). The Kemah locality thus shows a post-folding rotation of $6.7 \pm 5.4^{\circ} \mathrm{cw}$ (Figs. 3 and $6 z$, Table 1).

The Kalkar locality consists of the Kaleköy and Karaözü sections (Fig. 3), which were sampled for magnetostratigraphic purposes by Langereis et al. (1990) in upper Miocene (latest Vallesian; Sümengen et al., 1990) continental sediments. The continental sediments consist mainly of silts and brown clays with occasionally thick sand layers. We reinterpreted the demagnetization diagrams for tectonic purposes. A large overprint is only removed at relatively high temperatures (above $300^{\circ} \mathrm{C}$ ) and a final component trending towards the origin is only removed at the highest temperatures $\left(610-650{ }^{\circ} \mathrm{C}\right)$, pointing to maghemite and/or hematite as the main carrier of the ChRM. The Kalkar section yielded normal and reversed polarity directions that yield a positive reversal test in geographic coordinates but a negative one in tectonic coordinates. In tectonic coordinates the mean declination $\left(\sim 336 \pm 6^{\circ}\right)$ yields a $24 \pm 6^{\circ} \mathrm{ccw}$ rotation, but an inclination that is much shallower $\left(\sim 34^{\circ}\right)$ than in geographic coordinates $\left(60^{\circ}\right)$. We therefore interpret the locality as remagnetized after folding, with a rotation of $10.1 \pm 10.3^{\circ} \mathrm{cw}$ (Figs. 3 and 6aa, Table 1).

\section{Discussion}

\subsection{Regional vs. local rotation in the Ulukışla Basin}

The sampling of the Ulukışla Basin aimed to evaluate whether there is a significant rotation difference between the basin and the southern part of Kırşehir Block. Our results show that there are variations in the declinations derived from localities across the Upper Cretaceous to upper Miocene stratigraphy of the Ulukışla Basin (Fig. 2, Table 1). Because Eurasia has not significantly rotated around a vertical axis in this time interval (Torsvik et al., 2012), rotation differences found in our localities must have resulted from regional tectonics, also when results from Upper Cretaceous rocks are compared with those from Eocene rocks, for example. In the following we will discuss the meaning of each successful locality, evaluate the regional rotation of the basin, and discuss differences in the context of the major structures within the basin.

The majority of localities covering Paleocene to Oligocene sediments contain primary magnetizations that display evidence of counterclockwise rotations on the order of $\sim 20$ $40^{\circ}$. These include from east to west the Bekçili, Topraktepe, 
Kolsuz, Aktoprak, and Halkapınar localities. Together these localities provide an Oligocene or younger counterclockwise rotation of the basin of $32.3 \pm 2.2^{\circ}(n=326, K=16.4)$ when all individual directions are averaged or $32.2 \pm 9.0^{\circ} \quad(n=5$, $K=84.5$ ) when locality results are averaged.

In the southeastern parts of the basin, localities show rotations that strongly deviate from this average. The Upper Cretaceous and Paleocene sediments of the Alihoca locality in the southeast of the basin overlying ophiolite yielded a very large counterclockwise rotation of $\sim 90^{\circ}$. Gürer et al. (2016) showed that the southern sediments of the basin revealed phases of rapid uplift and subsequent subsidence in the Late Cretaceous. The uplift-subsidence-uplift-subsidence cycle was interpreted as the response to the underthrusting of the continental Kırşehir Block causing forearc uplift, then the potentially oceanic intra-Tauride basin causing forearc subsidence, and finally the Afyon Zone margin of the Taurides causing renewed uplift (Gürer et al., 2016, 2018). Paleocene subsidence was then accommodated along a major normal fault that bounds the basin to the south and that exhumed the Afyon Zone (Gürer et al., 2018), which was exposed immediately south of the Alihoca localities. Finally, the Alihoca locality is located close to the strike-slip EFZ. The strong local rotations in the Alihoca ophiolite are likely caused by these strong tectonic motions and structures and are not representative for the Ulukışla Basin. The Ardıçlı locality was sampled in Upper Cretaceous sediments in the immediate hanging wall of a thrust where a series of smaller strike-slip faults are also found (Gürer et al., 2016; Fig. 2). This locality yielded a post-folding clockwise rotation of $\sim 80^{\circ}$. The very low dispersion ( $K=147, A_{95}<A_{95_{\text {min }}}$ ) suggests undersampling of PSV and may be caused by later intrusion of mafic dykes into the Cretaceous stratigraphy of the locality. We also consider the Ardıçl rotation result as not regionally representative. Given the strong deformation, remagnetization (Ardıçlı), and indeterminate fold test (Alihoca), we interpret these localities to record strong local rotations. The upper Paleocene Kızılkapı sediments yielded counterclockwise rotations of $\sim 45^{\circ}$ before and a clockwise rotation of $\sim 13^{\circ}$ after tilt correction. As discussed above, inclinations are too steep after tectonic correction, while the post-folding counterclockwise rotation agrees well with the regional pattern. This indicates a post-tilt yet still pre-rotation magnetization, but given the inferred secondary nature of the magnetization, we refrain from using this locality in computing the rotation of the Ulukışla Basin. Finally, the Hasangazi locality of Eocene age defines a minor clockwise rotation. The sampled sites lie in a tightly folded plunging syncline in the footwall of the central top south-verging thrust (Fig. 2; Gürer et al., 2016). Hence, we interpret this rotation, even though well-defined, as a local rotation associated with the strong local deformation.

Finally, the available paleomagnetic information from Miocene stratigraphy shows a smaller rotation than the Paleocene to Oligocene localities. Our compilation of previously published paleomagnetic results from the upper Miocene to Pliocene rocks from the Cappadocia volcanic region, sampled across a large area of the southern Kırşehir Block (Çinku et al., 2016; Piper et al., 2002b, 2013; Platzman et al., 1998), yielded a minor counterclockwise rotation of $6 \pm 3^{\circ}$, suggesting that significant rotations predated the late Miocene. The poorly dated but presumed Miocene Postall locality in the northern part of the basin suggests a counterclockwise rotation of $17.7 \pm 5.4^{\circ}$, suggesting that part of the rotation may have extended into the Miocene, although the small areal coverage of the site cannot exclude a local rotation origin.

Lefebvre et al. (2013) obtained paleomagnetic data from four sites in Cretaceous granitoids in the southern Kırşehir Block (their Ağacören-Avanos Block, or $\mathrm{AAB}$ ) and concluded a $28-35^{\circ}$ counterclockwise rotation. We have recalculated the average direction of these four sites by averaging all individual directions, which yields a counterclockwise rotation of $28.7 \pm 2.8^{\circ}(n=248, K=14.8$; Table 1$)$. Comparing this number to our average from Ulukışla yields a negligible rotation difference of $3.6 \pm 3.6^{\circ}$, suggesting that the Ulukışla Basin and southern Kırşehir Block (the AAB of Lefebvre et al., 2013) form one coherently rotating domain, whereby our data from the Ulukışla Basin suggest an age of rotation sometime in or after the Oligocene, younger than the Paleocene-Eocene age postulated by Lefebvre et al. (2013). This age is consistent with the age of the Savc1l Thrust Zone (STZ; Lefebvre et al., 2013; Advokaat et al., 2014; Isik et al., 2014), which bounds the southern Kırşehir-Ulukışla rotating domain to the north. This thrust zone may continue into the Kurşunludag Thrust Zone in the east (Dirik and Göncüoglu, 1996).

\subsection{Relationship of rotation in the Central and Eastern Taurides with the Ulukışla Basin and the southern Kırşehir Block}

No paleomagnetic data are available from the carbonates of the Taurides in the Bolkar Mountains immediately to the south of the Ulukışla Basin (and to the east of the Berendi locality) to test whether the Central Taurides are part of the same rotating domain. Our results from the Eocene sediments of the Berendi locality overlying the Central Taurides show that $17 \pm 6^{\circ} \mathrm{ccw}$ rotation occurred following a postfolding remagnetization. We cannot constrain the timing of the folding or the remagnetization, which may thus have occurred anytime since the (post-)Oligocene $\sim 30^{\circ} \mathrm{ccw}$ rotation of the Ulukışla Basin and the AAB. The Berendi results, however, do suggest that the Bolkar Mountains were not part of the clockwise-rotating domain documented in the west-central Taurides to the northwest of the Mut basin (Çinku et al., 2016; Kissel et al., 1993; Meijers et al., 2011). The Bolkar Mountains are separated by a fault from the Ulukışla Basin that was previously interpreted as a major back-thrust (Blumenthal, 1956; Demirtasli et al., 1984). Gürer et al. $(2016,2017)$, however, showed that this fault 
is a folded and overturned normal fault that was sealed by Eocene sediments. Although this normal fault may have accommodated a rotation difference between the Ulukışla Basin and the Bolkar Mountains during its Paleocene to early Eocene activity, it is unlikely that it accommodated major differential rotation differences since the middle Eocene. The formation of the Bolkar fold in the Oligocene time was associated with no more than a few kilometers of shortening, which is unlikely to have resulted in a major differential rotation. We therefore conclude that the Bolkar Mountains formed a coherent part of the counterclockwise-rotating domain together with the Ulukışla Basin and the southern Kırşehir Block.

Paleomagnetic data from Cinku et al. (2016) show that immediately east of the EFZ, the amount of rotation measured in Upper Cretaceous carbonates increases slightly towards the fault. Combining all their (parametrically sampled) sites yields a declination of $318.5 \pm 3.0^{\circ}$, suggesting a net counterclockwise vertical axis rotation of $41.5 \pm 3^{\circ}$ ( $n=154, K=16.1$; Fig. 1, arrow with reference 11). Farther towards the east, where the strike of the Eastern Taurides changes from NE-SW to ENE-WSW, the paleomagnetic data from the Tauride units are sparse, but four sites of Kissel et al. (2003) and Cinku et al. (2016; Fig. 1, arrows with references 4 and 11, Eastern Taurides locality in Fig. 3) from Eocene limestones yield a declination of $329.8 \pm 3.8^{\circ}$ $(n=80, K=22.3)$, suggesting a $30.2 \pm 3.8^{\circ} \mathrm{ccw}$ rotation. Our Eocene Akkışla locality immediately north of the Eastern Taurides (Fig. 3) showed a $27.6 \pm 3.7^{\circ} \mathrm{ccw}$ rotation, within error identical to that of the Eastern Tauride carbonates. Together, these thus provide a rotation that is indistinguishable from the rotation obtained from the Ulukışla Basin and the southern Kırşehir Block.

The $\sim 10^{\circ}$ rotation difference between the Cretaceous sites close to the EFZ (Fig. 1 arrow with reference 3; Çinku et al., 2016) and the Eocene sites towards the east may be explained in two ways. They may represent a small rotation associated with drag folding along the left-lateral EFZ. Alternatively, they may indicate a $\sim 10^{\circ}$ rotation occurring between the Late Cretaceous and the Eocene, when the Tauride rocks were still connected to the downgoing African Plate. Between $\sim 80$ and $\sim 50 \mathrm{Ma}$, Africa experienced a $10^{\circ} \mathrm{ccw}$ rotation. In the absence of a detailed structural model for the Eastern Taurides showing from which nappes the paleomagnetic data were obtained and when those nappes were incorporated into the Tauride fold-and-thrust belt, we cannot determine which of these two solutions is the more likely. We interpret that the Taurides have undergone a coherent $30^{\circ} \mathrm{ccw}$ rotation since the Oligocene time and that the shearing along the EFZ did not lead to strong regional extra rotations.

Oligocene sediments overlying the Eastern Tauride foldand-thrust belt in our Aladağ locality reveal a post-folding magnetization and a $17 \pm 7^{\circ} \mathrm{ccw}$ rotation. Since the timing of its remagnetization cannot be constrained and may well have occurred during the rotation phase, this sheds no light on the timing of the Eastern Tauride rotation. Our Miocene site Gürün shows a counterclockwise rotation of $16 \pm 11^{\circ}$ (Fig. 3, Table 1), and the Kepezdağ and Yamadağ localities of Gürsoy et al. (2011) obtained from middle Miocene (13-15 Ma) lavas show $26 \pm 20^{\circ}$ and $28 \pm 6^{\circ} \mathrm{ccw}$, respectively (Fig. 1, arrows with reference 6). Taken together, those data may suggest that the Eastern Tauride rotations occurred in the middle Miocene or a younger time, but we note that these Miocene lavas were sampled in the close vicinity of middle Miocene and younger left-lateral strike-slip faults (Westaway and Arger, 2001; Kaymakci et al., 2010) and may thus not be representative of the timing of regional rotation. Three sites (Fig. 1; arrows with references 8 and 11) from middle and upper Miocene sediments in the Adana Basin (Çinku et al., 2016; Lucifora et al., 2012) yield a declination of $354.3 \pm 3.8^{\circ}(n=134, K=14.4)$, suggesting a minor rotation of $5.7 \pm 3.8^{\circ}$ and thus a pre-middle Miocene rotation. We tentatively suggest that the regional rotation of the Eastern Taurides occurred sometime between the Eocene and middle Miocene and was further locally modified by Miocene left-lateral strike-slip faults.

Overall, the sense and magnitude of the Central and Eastern Tauride rotations, those obtained from the stratigraphy of the Ulukışla Basin, and those previously reported from the southern part of the Kırşehir Block (Lefebvre et al., 2013) suggest that the region rotated as a more or less coherent block, which has undergone a counterclockwise rotation of $\sim 30^{\circ}$ (largely) sometime in the Oligocene or early Miocene time.

\subsection{Rotations in the Sivas Basin and the boundary of the Southeast Anatolian counterclockwise-rotating domain}

Our results from the Sivas Basin show that extensive sampling was required to obtain rotation patterns, as only $\sim 30 \%$ of samples and sites yielded meaningful paleomagnetic results. This is largely caused by (true or suspected) postfolding remagnetization, particularly to the north of the Deliler-Tecer Fault Zone (DTFZ). Nevertheless, our results lead us to the following first-order interpretation of rotations in the Sivas Basin.

We subdivide the Sivas region into three domains (Fig. 8). These are (1) the area exposing Eocene and Oligocene sediments to the south of and in the footwall of the top-to-thesouth DTFZ, (2) the area exposing Paleogene sediments immediately north and in the hanging wall of this thrust zone, and (3) the Miocene and younger sediments occupying the northernmost part of the basin. The rotations in the Oligocene corridor of the southern domain are constrained (from east to west) by the Sincan, Inkonak, and Yeniköy localities (Fig. 3), which reveal a combined counterclockwise rotation of $48.1 \pm 2.9^{\circ}(n=191, K=15.8)$. The middle Miocene Gemerek locality (Krijgsman et al., 1996) also yielded such high rotations $\left(49.9 \pm 3.8^{\circ}\right.$; Table 1$)$. Interestingly, these ro- 


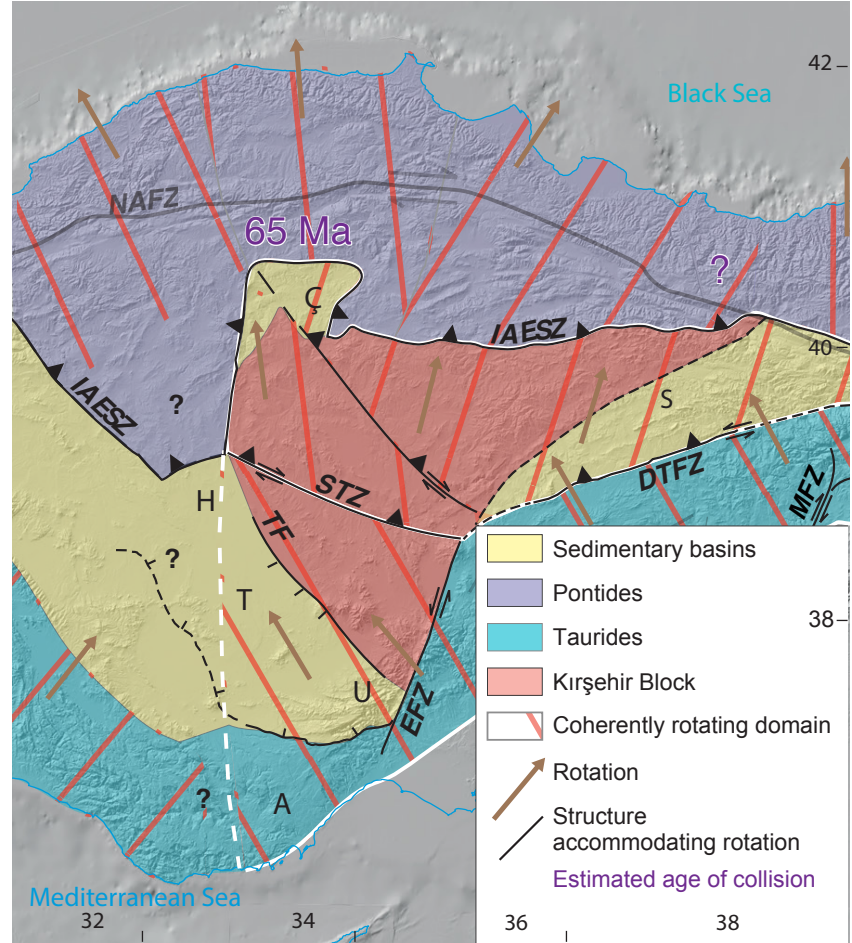

Figure 8. Coherently rotating domains within the Anatolian orogen and tectonic structures accommodating differential rotations. NAFZ - North Anatolian Fault Zone, IAESZ - Izmir-AnkaraErzincan Suture Zone, STZ - Savcılı Thrust Zone, DTFZ - DelilerTecer Fault Zone, TF - Tuzgölü Fault, EFZ - Ecemiş Fault Zone, MFZ - Malatya Fault Zone. Basins: U - Ulukışla, T - Tuzgölü, $\mathrm{H}$ - Haymana, A - Adana. Orange hatching indicates the amount of vertical axis rotation of each domain, whereby the hatching is rotated from north to south according to the paleomagnetic results summarized in Table 1.

tations are $\sim 15-20^{\circ}$ more ccw than those recorded in the Eastern Tauride fold-and-thrust belt. This difference may be interpreted in different ways. On the one hand, it may suggest that the Taurides underwent a clockwise rotation between the Eocene and Oligocene of $15-20^{\circ}$, followed by a $50^{\circ}$ rotation after deposition of the middle Miocene Gemerek section. This, however, is inconsistent with the directions obtained from Oligocene sediments in the Ulukışla Basin or Miocene sediments overlying the Taurides (Fig. 2). We thus assume that the area to the south of the DTFZ was part of the Eastern Tauride rotating domain and tentatively ascribe the excess $\sim 15^{\circ}$ rotation to the local deformation in the footwall of the DTFZ, e.g., introduced by a sinistral component of the fault zone as postulated by Yilmaz and Yilmaz (2006).

A distinct break in rotation sense occurs across the DTFZ (Figs. 3 and 8), north of which rotations are variable but generally clockwise, rotating as much as $\sim 30^{\circ}$ in the central and northern part of the basin (Gürlevik, Ulaş, Sivas, Kemah localities). Explaining the variable clockwise rotations is not straightforward, but well-documented intense deformation in
Table 2. Apparent polar wander path calculated from published and new site averages of SE Anatolia. Poles integrate site averages from $20 \mathrm{Myr}$ sliding windows, i.e., for the $10 \mathrm{Ma}$ pole, all sites with ages of 0-20 Ma were averaged; $n$ is the number of sites. $A_{95}$ is the cone of confidence around the pole.

\begin{tabular}{lrrrr}
\hline Age (Ma) & $n$ & Latitude & Longitude & $A_{95}$ \\
\hline 10 & 11 & 74.5 & 277.7 & 8.7 \\
20 & 15 & 63.0 & 290.0 & 8.6 \\
40 & 24 & 65.3 & 278.4 & 6.0 \\
50 & 28 & 63.3 & 277.5 & 5.1 \\
60 & 9 & 60.7 & 276.8 & 8.2 \\
70 & 9 & 64.9 & 281.5 & 11.3 \\
80 & 9 & 60.8 & 292.2 & 9.7 \\
130 & 4 & 46.1 & 289.3 & 9.0 \\
\hline
\end{tabular}

part associated with intense local salt tectonics (Kergaravat et al., 2016; Pichat et al., 2016; Poisson et al., 2016; Ribes et al., 2015) may provide an explanation. We note, however, that one Oligocene locality (Güllük) to the north of the DTFZ reveals the counterclockwise rotations characteristic of the area to its south. Farther to the north, in the eastern Kirşehir Block or the eastern Pontides north of the North Anatolian Fault Zone, no major counterclockwise rotations were reported. The northeastern Kırşehir Block (the AYB Block of Lefebvre et al., 2013) experienced $18.4 \pm 6.0^{\circ}$ clockwise rotation measured in Upper Cretaceous granitoids. The eastern Pontides experienced only minor rotations since the Late Cretaceous-Eocene time, and there is a compilation of existing data (Baydemir, 1990; Channell et al., 1996; Kissel et al., 2003; Meijers et al., 2010; Orbay and Bayburdi, 1979; van der Voo, 1968).

We therefore suggest that the boundary of the coherently counterclockwise-rotating domain of the Eastern Taurides most likely coincides with the Deliler-Tecer Fault Zone (DTFZ; Fig. 8). Previously, Lefebvre et al. (2013) suggested that the counterclockwise rotation of the southern Kırşehir Block was bounded in the north along the top-to-thesouth Savc1lı Thrust Zone (STZ), below which deformed and folded sediments are found that are similar in age and facies as those below the DTFZ. Given this similarity and the coherence in rotation direction, amount, and timing, we infer that the counterclockwise-rotating domain of Central and Southern Anatolia comprised of the southern Kırşehir Block, the Ulukışla Basin, the Bolkar Mountains, the Eastern Taurides, and the southern part of the Sivas Basin was bounded to the north by a thrust fault zone comprised of the STZ in the west and the DTFZ in the east. Using all published and new paleomagnetic sites from Cretaceous to Neogene rocks in this rotating domain, we computed an apparent polar wander path (Fig. 9, Table 2) for the SE Anatolian rotating block. From this APWP, it is clear that this domain rotated $\sim 30-35^{\circ} \mathrm{ccW}$ relative to Eurasia, largely in the Oligo-Miocene time. As mentioned above, the declination trend for the Cretaceous is 


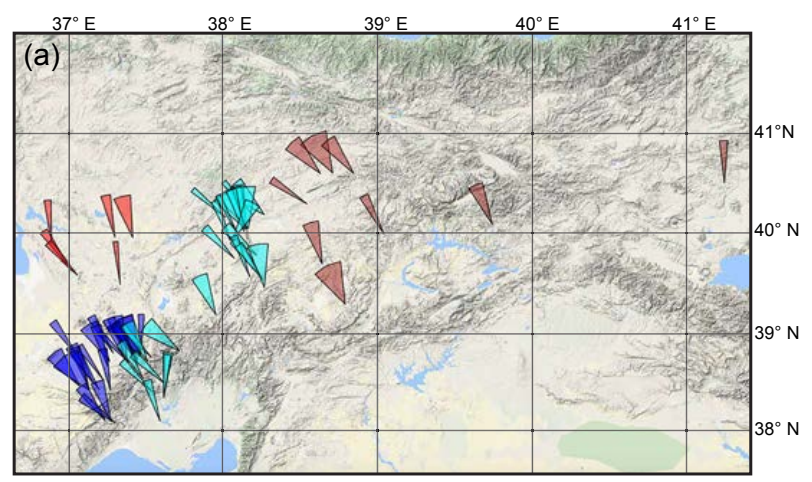

40 (b)

Reference location: $38.1^{\circ} \mathrm{N} \quad 35.5^{\circ} \mathrm{E}$
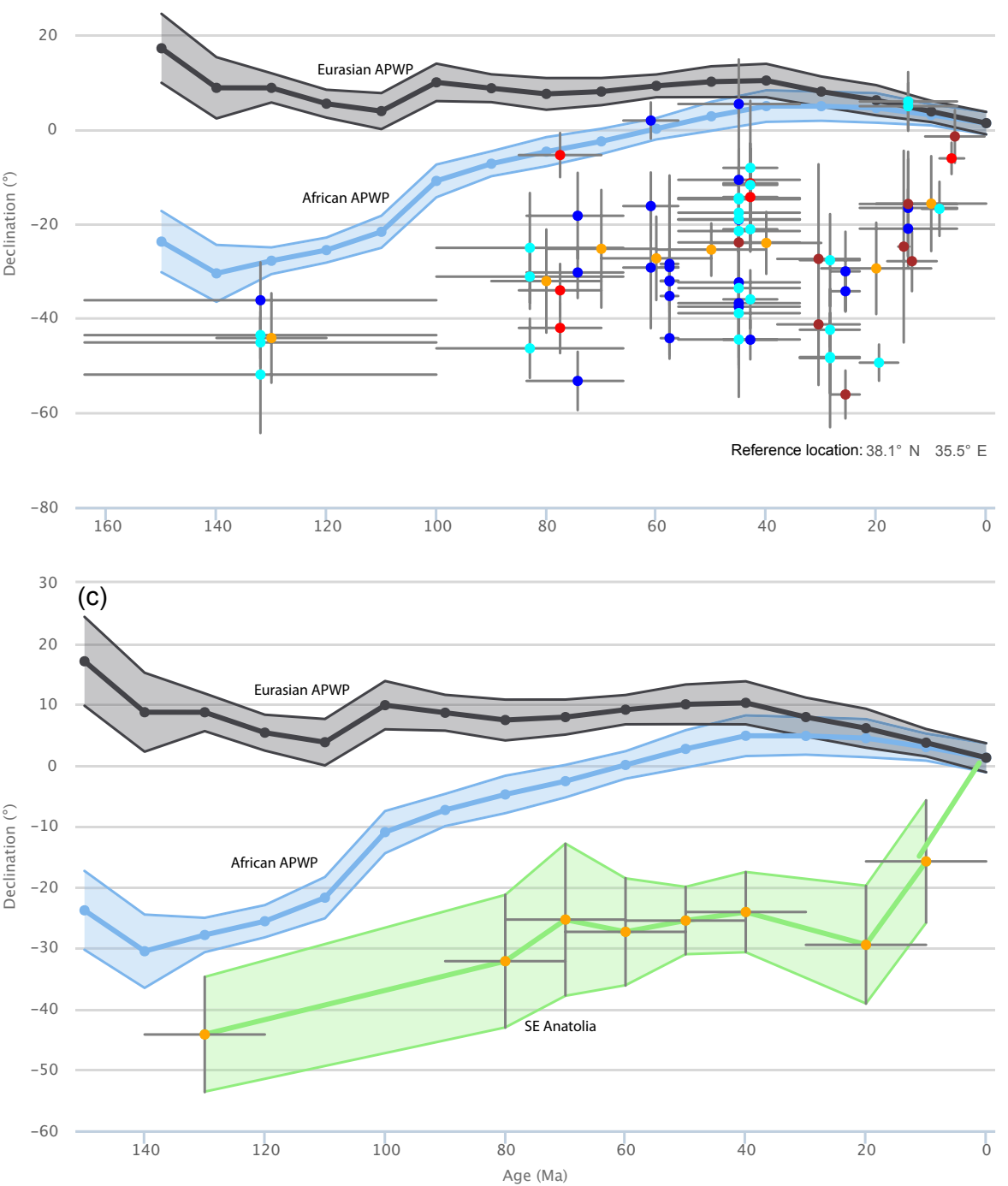

Figure 9. (a) Published and new paleomagnetic sites from the SE Anatolian rotating domain used to calculate an apparent polar wander path for the block in (c). Color coding subdivides the sites into four regions. This shows (b) that the APWP is not significantly biased by the deviating declinations of one region. Reference APWPs for Africa and Eurasia come from Torsvik et al. (2012). 
parallel to Africa, confirming that the Taurides in that time were still part of the African Plate.

Finally, the Eastern Taurides appear to have rotated coherently with the southern Kırşehir Block and the Ulukışla Basin, but we note that they were displaced relative to the latter along the EFZ (Fig. 8). This fault is controlled by the eastern margin of the Kurşehir Block, and its left-lateral displacement requires that the Sivas Basin underwent 60-70 km more $\mathrm{N}-\mathrm{S}$ Eocene-early Miocene convergence than Central Anatolia. This excess convergence is likely responsible for the much stronger deformation and probably the more disperse rotation patterns associated with the structural growth of the Sivas fold-and-thrust belt.

\section{Conclusion}

In this paper, we provide a large set of new paleomagnetic data from central-southern and central-eastern Anatolia to aid kinematic restoration of the Anatolian Orogen. We aimed to identify the timing, amount, and regional coherence of rotating blocks in Central and Southern Anatolia. Our main findings can be summarized as follows.

The Ulukışla Basin underwent a regional counterclockwise rotation of $\sim 32.5 \pm 2.2^{\circ}$ in Oligocene and Miocene times, which is comparable with the amount and sense of rotation $\left(28-35^{\circ}\right)$ previously reported for the southern part of the Kurşehir Block. This rotation phase is contemporaneous with the activity of the STZ as a contractional structure, the onset of the major left-lateral EFZ, and possibly with similar structures within the Eastern Taurides (e.g., Malatya Fault (MFZ) in Figs. 1 and 8). Deviations from this regionally consistent pattern are found in the southern and southeastern part of the basin, where local rotations strongly deviate from this average owing to vicinity to major tectonic structures, such as the EFZ.

We find $\sim 17$ counterclockwise rotations in Eocene but remagnetized sedimentary rocks overlying the Central Tauride fold-and-thrust belt in the Bolkar Mountains. This suggests that the Bolkar Mountains were part of the counterclockwiserotating domain as opposed to the clockwise rotations found in the western-central Taurides. The total amount of counterclockwise rotation since the Eocene cannot be determined due to remagnetization, but the absence of a major Oligocene or younger fault between the Ulukışla Basin and the Bolkar Mountains leads us to include these in the counterclockwiserotating South Anatolian domain.

Counterclockwise rotations were previously reported from the Eastern Taurides. These show a comparable $\sim 30^{\circ} \mathrm{ccw}$ rotation since the Eocene. Larger ccw rotations are reported close to the EFZ, which dissects the Taurides in the central and eastern parts and plays a major role in the growth of the Sivas fold-and-thrust belt. Our new paleomagnetic data from the Sivas fold-and-thrust belt reveal that on average $\sim 48^{\circ}$ counterclockwise rotations can be traced into the footwall of the DTFZ. In the hanging wall of this thrust, paleomagnetic data quality is generally low, but successful sites show consistently minor $\left(7-20^{\circ}\right)$ clockwise rotations.

We conclude that the southern Kırşehir Block, Ulukışla Basin, Bolkar Mountains, Eastern Taurides, and the southern part of the Sivas Basin were part of one coherently counterclockwise-rotating domain that experienced $\sim 30^{\circ}$ rotation in the Oligocene or earliest Miocene time. Structural constraints suggest that this domain was bounded in the north by the STZ and DTFZ and in the south by the AfricanArabian trench. To the west, the boundary is diffuse and requires future study.

Data availability. The underlying research data are publicly accessible on the PANGAEA ${ }^{\circledR}$ Data Publisher, https://doi.pangaea.de/10. 1594/PANGAEA.887421 (Gürer et al., 2018).

\section{Information about the Supplement}

\section{Supplementary information 1}

Paleomagnetic data files compatible with paleomagnetism. org (Koymans et al., 2016) are used in this paper. Paleomagnetic demagnetization files are provided in a folder with.dir files and contain demagnetization diagrams and our interpretations, viewable in the interpretation portal at paleomagnetism.org. The folder with.pmag files contains the statistical parameters of sites and localities discussed in this paper, which are provided as separate files for the Ulukışla, Sivas, and Tauride basins. In addition, we provide a file with parametrically sampled literature data compiled from Baydemir (1990), Channell et al. (1996), Cinku et al. (2016), Gürsoy et al. (2003, 2011), Hisarlı et al. (2016), Kissel et al. (2003), Lefebvre et al. (2013), Lucifora et al. (2012), Meijers et al. (2010, and references therein), Orbay and Bayburdi (1979), Piper et al. (2002a, b, 2013), Platzman et al. (1998), Saribudak (1989), Tatar et al. (2000), and Van der Voo (1968).

\section{Supplementary information 2}

Detailed biostratigraphic constraints obtained from calcareous nannofossils are provided for the Berendi locality in the Central Taurides.

\section{The Supplement related to this article is available online at https://doi.org/10.5194/se-9-295-2018-supplement.}

Author contributions. DG and DJJvH designed the study. DG and MÖ carried out the bulk of the sampling, with support from DJJvH, IC, MK, and CL. IC and MK helped with acquiring paleomagnetic 
data. AC provided biostratigraphic constraints. CL, DG, DJJvH, and MÖ interpreted the data. DG and DJJvH prepared the paper.

Competing interests. The authors declare that they have no conflict of interest.

Acknowledgements. Derya Gürer and Douwe J. J. van Hinsbergen were supported by ERC starting grant 306810 . Douwe J. J. van Hinsbergen acknowledges NWO Vidi grant 864.11.004. Pinar Ertepinar and Nur Güneli are thanked for field assistance and logistical support. Wout Krijgsman is thanked for providing the original data files of a previously published dataset. Aral Okay, Giovanni Muttoni, and two anonymous reviewers are thanked for useful comments.

Edited by: Federico Rossetti

Reviewed by: Aral Okay, Giovanni Muttoni, and two anonymous referees

\section{References}

Advokaat, E. L., van Hinsbergen, D. J. J., Kaymakci, N., Vissers, R. L. M., and Hendriks, B. W. H.: Late Cretaceous extension and Palaeogene rotation-related contraction in central Anatolia recorded in the Ayhan-Büyükkışla basin, Int. Geol. Rev., 56, 1813-1836, https://doi.org/10.1080/00206814.2014.954279, 2014.

Akyuz, H. S., Ucarkus, G., Altunel, E., Dogan, B., and Dikbas, A.: Paleoseismological investigations on a slow-moving active fault in central Anatolia, Tecer Fault, Sivas, Ann. Geophys., 55, https://doi.org/10.4401/ag-5444, 2013.

Alan, I., Şahin, Ş., and Bakırhan, B.: Turkish Geological Map Series, Adana N33, General Directorate of Mineral Research and Exploration (MTA), Ankara, 2011.

Atabey, E., Göncüoglu, M. C., and Turhan, N.: Turkish Geological Map Series, Kozan M33 (J19), General Directorate of Mineral Research and Exploration (MTA), Ankara, 1990.

Barrier, E. and Vrielynck, B.: Palaeotectonic maps of the middle east - Middle Aptian, in: Atlas of 14 maps at 1/18500000, CGMW, Paris, France, 2008.

Baydemir, N.: Palaeomagnetism of the Eocene volcanic rocks in the eastern Black Sea region, J. Earth Sci., 7, 167-176, 1990.

Blumenthal, M. M.: Yüksek Bolkardağın kuzey kenar bölgelerinin ve batı uzantılarının jeolojisi: (Güney Anadolu Torosları), Maden Tetkik ve Arama Enstitüsü, Ankara, 1956.

Boztuğ, D., Jonckheere, R. C., Heizler, M., Ratschbacher, L., Harlavan, Y., and Tichomirova, M.: Timing of post-obduction granitoids from intrusion through cooling to exhumation in central Anatolia, Turkey, Tectonophysics, 473, 223-233, https://doi.org/10.1016/j.tecto.2008.05.035, 2009.

Butler, R. F.: Paleomagnetism: Magnetic Domains to Geologic Terranes, Blackwell Scientific Publications, 1992.

Callot, J.-P., Ribes, C., Kergaravat, C., Bonnel, C., Temiz, H., Poisson, A., Vrielynck, B., Salel, J.-F., and Ringenbach, J.-C.: Salt tectonics in the Sivas Basin (Turkey): crossing salt walls and minibasins, B. Soc. Geol. Fr., 185, 33-42, 2014.
Cater, J. M. L., Hanna, S. S., Ries, A. C., and Turner, P.: Tertiary evolution of the Sivas Basin, central Turkey, Tectonophysics, 195, 29-46, 1991.

Channell, J. E. T., Tüysüz, O. O. B., and Şengör, A. M. C.: Cretaceous paleomagnetism and paleogeography of the Pontides (Turkey), Tectonics, 15, 201-212, 1996.

Çinku, M. C., Hisarlı, Z. M., Heller, F., Orbay, N., and Ustaömer, T.: Middle Eocene paleomagnetic data from the eastern Sakarya Zone and the central Pontides: Implications for the tectonic evolution of north central Anatolia, Tectonics, 30, TC1008, https://doi.org/10.1029/2010TC002705, 2011.

Clark, M. and Robertson, A.: The role of the Early Tertiary Ulukisla Basin, southern Turkey, in suturing of the Mesozoic Tethys ocean, J. Geol. Soc. London, 159, 673-690, https://doi.org/10.1144/0016-764902-015, 2002.

Clark, M. and Robertson, A.: Uppermost Cretaceous-Lower Tertiary Ulukisla Basin, south-central Turkey: sedimentary evolution of part of a unified basin complex within an evolving neotethyan suture zone, Sediment. Geol., 173, 15-51, https://doi.org/10.1016/j.sedgeo.2003.12.010, 2005.

Çemen, I., Göncüoglu, M. C., and Dirik, K.: Structural evolution of the Tuzgölü Basin in central Anatolia, Turkey, J. Geol., 107, 693-706, 1999.

Çinku, M. C., Hisarli, Z. M., Yılmaz, Y., Ülker, B., Kaya, N., Öksüm, E., Orbay, N., and Özbey, Z. Ü.: The tectonic history of the Niğde-Kırşehir Massif and the Taurides since the Late Mesozoic: paleomagnetic evidence for two-phase orogenic curvature in central Anatolia, Tectonics, 35, 772-811, 2016.

Dankers, P. H. M.: Magnetic properties of dispersed natural ironoxides of known grain size, $\mathrm{PhD}$ Thesis, Utrecht University, Utrecht, 143 pp., 1978.

Dankers, P. H. M. and Zijderveld, J. D. A.: Alternating field demagnetization of rocks, and the problem of gyromagnetic remanence, Earth Planet. Sc. Lett., 53, 89-92, 1981.

Deenen, M. H. L., Langereis, C. G., van Hinsbergen, D. J. J., and Biggin, A. J.: Geomagnetic secular variation and the statistics of palaeomagnetic directions, Geophys. J. Int., 186, 509-520, https://doi.org/10.1111/j.1365-246X.2011.05050.x, 2011.

Deenen, M. H. L., Langereis, C. G., van Hinsbergen, D. J. J., and Biggin, A. J.: Erratum: Geomagnetic secular variation and the statistics of palaeomagnetic directions, Geophys. J. Int., 197, 643-643, 2014.

Dekkers, M. J.: Magnetic properties of natural pyrrhotite Part I: Behaviour of initial susceptibility and saturation-magnetizationrelated rock-magnetic parameters in a grain-size dependent framework, Phys. Earth Planet. In., 52, 376-393, 1988.

Demirtasli, E., Turhan, N., Bilgin, A. Z., and Selim, M.: Geology of the Bolkar Mountains, in: Geology of the Taurus Belt, Proceedings of the International Symposium on the Geology of the Taurus Belt, Ankara, Turkey, Mineral Resources and Exploration Institute of Turkey, Ankara, 12-141, 1984.

Dirik, K. and Göncüoglu, M. C.: Neotectonic characteristics of central Anatolia, Int. Geol. Rev., 38, 807-817, 1996.

Dokuz, A., Aydincakir, E., Kandemir, R., Karsli, O., Siebel, W., Derman, A. S., and Turan, M.: Late Jurassic magmatism and stratigraphy in the eastern Sakarya Zone, Turkey: evidence for the slab breakoff of Paleotethyan oceanic lithosphere, J. Geol., $125,1-31,2017$. 
Espurt, N., Hippolyte, J.-C., Kaymakci, N., and Sangu, E.: Lithospheric structural control on inversion of the southern margin of the Black Sea Basin, central Pontides, Turkey, Lithosphere, 6, 26-34, https://doi.org/10.1130/1316.1, 2014.

Fisher, R.: Dispersion on a sphere, P. Roy. Soc. A, 217, 295-305, https://doi.org/10.1098/rspa.1953.0064, 1953.

Gautier, P., Bozkurt, E., Hallot, E., and Dirik, K.: Dating the exhumation of a metamorphic dome: geological evidence for pre-Eocene unroofing of the Nigde Massif (central Anatolia, Turkey), Geol. Mag., 139, 559-576, https://doi.org/10.1017/S0016756802006751, 2002.

Gautier, P., Bozkurt, E., Bosse, V., Hallot, E., and Dirik, K.: Coeval extensional shearing and lateral underflow during Late Cretaceous core complex development in the Niğde Massif, central Anatolia, Turkey, Tectonics, 27, TC1003, https://doi.org/10.1029/2006TC002089, 2008.

Göncüoglu, M. C.: Distribution of Lower Paleozoic rocks in the Alpine terranes of Turkey. Early Paleozoic in NW Gondwana, edited by: Göncüoglu, M. C. and Derman, A. S., Turkish Association of Petroleum Geologists Special Publication, 3, 13-23, 1997.

Gülyüz, E., Kaymakci, N., Meijers, M. J. M., Hinsbergen, D. J. J. Van, Lefebvre, C., Vissers, R. L. M., Hendriks, B. W. H., and Peynircioglu, A. A.: Tectonophysics Late Eocene evolution of the Çiçekdağ 1 Basin (central Turkey): synsedimentary compression during microcontinent - continent collision in central Anatolia, Tectonophysics, 602, 286-299, https://doi.org/10.1016/j.tecto.2012.07.003, 2013.

Gürer, D., van Hinsbergen, D. J., Matenco, L., Corfu, F., and Cascella, A.: Kinematics of a former oceanic plate of the Neotethys revealed by deformation in the Ulukışla Basin (Turkey), Tectonics, 35, 2385-2416, https://doi.org/10.1002/2016TC004206, 2016.

Gürer, D., Plunder, A., Kirst, F., Corfu, F., Schmid, S. M., and van Hinsbergen, D. J. J.: A long-lived Late Cretaceous-Early Eocene extensional province in Anatolia? Structural evidence from the Ivriz Detachment, southern central Turkey, Earth Planet. Sc. Lett., 481, 111-124, 2018.

Gürer, D., van Hinsbergen, D. J. J., Özkaptan, M., Creton, I., Koymans, M. R., Cascella, A., and Langereis, C. G.: Paleomagnetic dataset: constraints on the timing and distribution of Cenozoic rotations in Central and Eastern Anatolia, PANGAEA, https: //doi.pangaea.de/10.1594/PANGAEA.887421, 2018.

Gürsoy, H., Tatar, O., Piper, J. D. A., Koçbulut, F., Akpınar, Z., Huang, B., Roberts, A. P., and Mesci, B. L.: Palaeomagnetic study of the Kepezdağ and Yamadağ volcanic complexes, central Turkey: neogene tectonic escape and block definition in the central-east Anatolides, J. Geodyn., 51, 308-326, 2011.

Gutnic, M., Monod, O., Poisson, A., and Dumont, J.-F.: Géologie des Taurides occidentales (Turquie), Mem. S. Geo. F., 137, 1112, 1979.

Heslop, D. and Roberts, A. P.: Analyzing paleomagnetic data: to anchor or not to anchor?, J. Geophys. Res.-Sol. Ea., 121, 77427753, https://doi.org/10.1002/2016JB013387, 2016.

Higgins, M., Schoenbohm, L. M., Brocard, G., Kaymakci, N., Gosse, J. C., and Cosca, M. A.: New kinematic and geochronologic evidence for the Quaternary evolution of the Central Anatolian Fault Zone (CAFZ), Tectonics, 34, 2118-2141, 2015.
Hisarlı, Z. M., Çinku, M. C., Ustaömer, T., Keskin, M., and Orbay, N.: Neotectonic deformation in the Eurasia-Arabia collision zone, the East Anatolian Plateau, E Turkey: evidence from palaeomagnetic study of Neogene-Quaternary volcanic rocks, Int. J. Earth Sci., 105, 139-165, 2016.

Isik, V.: The ductile shear zone in granitoid of the Central Anatolian Crystalline Complex, Turkey: implications for the origins of the Tuzgölü Basin during the Late Cretaceous extensional deformation, J. Asian Earth Sci., 34, 507-521, https://doi.org/10.1016/j.jseaes.2008.08.005, 2009.

Isik, V., Lo, C.-H., Göncüoğlu, C., and Demirel, S.: ${ }^{39} \mathrm{Ar} /{ }^{40} \mathrm{Ar}$ ages from the Yozgat Batholith: preliminary data on the timing of Late Cretaceous Extension in the Central Anatolian Crystalline Complex, Turkey, J. Geol., 116, 510-526, https://doi.org/10.1086/590922, 2008.

Isik, V., Uysal, I. T., Caglayan, A., and Seyitoglu, G.: The evolution of intraplate fault systems in central Turkey: structural evidence and $\mathrm{Ar}-\mathrm{Ar}$ and $\mathrm{Rb}-\mathrm{Sr}$ age constraints for the Savcili Fault Zone, Tectonics, 33, 1875-1899, 2014.

Jaffey, N. and Robertson, A. H. F.: New sedimentological and structural data from the Ecemis Fault Zone, southern Turkey: implications for its timing and offset and the Cenozoic tectonic escape of Anatolia, J. Geol. Soc. London, 158, 367-378, https://doi.org/10.1144/jgs.158.2.367, 2001.

Johnson, C. L., Constable, C. G., Tauxe, L., Barendregt, R., Brown, L. L., Coe, R. S., Layer, P., Mejia, V., Opdyke, N. D., Singer, B. S., and Staudigel, H.: Recent investigations of the 0$5 \mathrm{Ma}$ geomagnetic field recorded by lava flows, Geochem. Geophy. Geosy., 9, Q04032, https://doi.org/10.1029/2007GC001696, 008.

Kaymakci, N., Duermeijer, C. E., Langereis, C., White, S. H., and Van Dijk, P. M.: Palaeomagnetic evolution of the Cankiri Basin (central Anatolia, Turkey): implications for oroclinal bending due to indentation, Geol. Mag., 140, 343-355, https://doi.org/10.1017/S001675680300757X, 2003.

Kaymakci, N., Özçelik, Y., White, S. H., and Van Dijk, P. M.: Tectono-stratigraphy of the Çankırı Basin: Late Cretaceous to Early Miocene evolution of the Neotethyan suture zone in Turkey, Geol. Soc. Spec. Publ., 311, 67-106, 2009.

Kaymakci, N., Inceoz, M., Ertepinar, P., and Koc, A.: Late Cretaceous to recent kinematics of SE Anatolia (Turkey), Geol. Soc. Spec. Publ., 340, 409-435, https://doi.org/10.1144/SP340.18, 2010.

Kergaravat, C., Ribes, C., Legeay, E., Callot, J.-P., Kavak, K. S., and Ringenbach, J.-C.: Minibasins and salt canopy in foreland foldand-thrust belts: the central Sivas Basin, Turkey, Tectonics, 35, 1342-1366, 2016.

Kirschvink, J. L.: The least-squares line and plane and the analysis of palaeomagnetic data, Geophys. J. Int., 62, 699-718, https://doi.org/10.1111/j.1365-246X.1980.tb02601.x, 1980.

Kissel, C., Averbuch, O., de Lamotte, D. F., Monod, O., and Allerton, S.: First paleomagnetic evidence for a post-Eocene clockwise rotation of the western Taurides thrust belt east of the Isparta reentrant (southwestern Turkey), Earth Planet. Sc. Lett., 117, 114, https://doi.org/10.1016/0012-821X(93)90113-N, 1993.

Kissel, C., Lai, C., Poisson, A., and Görür, N.: Paleomagnetic reconstruction of the Cenozoic evolution of the eastern Mediterranean, Tectonophysics, 362, 199-217, https://doi.org/10.1016/S00401951(02)00638-8, 2003. 
Koymans, M. R., Langereis, C. G., Pastor-Galán, D., and van Hinsbergen, D. J. J.: Paleomagnetism.org: an online multi-platform open source environment for paleomagnetic data analysis, Comput. Geosci., 93, 127-137, https://doi.org/10.1016/j.cageo.2016.05.007, 2016.

Krijgsman, W., Duermeijer, C. E., Langereis, C. G., de Bruijn, H., Saraç, G., and Andriessen, P. A. M.: Magnetic polarity stratigraphy of Late Oligocene to Middle Miocene mammal-bearing continental deposits in central Anatolia (Turkey), Newsl. Stratigr., 34, 13-29, 1996.

Langereis, C. G., Sen, S., Sümengen, M., and Ünay, E.: Preliminary magnetostratigraphic results of some neogene mammal localities from Anatolia (Turkey), in: European Neogene Mammal Chronology, NATO ASI Series (Series A: Life Sciences), Vol. 180, Springer, Boston, MA, 515-525, 1990.

Lefebvre, C., Barnhoorn, A., van Hinsbergen, D. J. J., Kaymakci, N., and Vissers, R. L. M.: Late Cretaceous extensional denudation along a marble detachment fault zone in the Kırşehir Massif near Kaman, central Turkey, J. Struct. Geol., 33, 12201236, https://doi.org/10.1016/j.jsg.2011.06.002, 2011.

Lefebvre, C., Meijers, M. J. M., Kaymakci, N., Peynircioğlu, A., Langereis, C. G., and van Hinsbergen, D. J. J.: Reconstructing the geometry of central Anatolia during the late Cretaceous: large-scale Cenozoic rotations and deformation between the Pontides and Taurides, Earth Planet. Sc. Lett., 366, 83-98, https://doi.org/10.1016/j.eps1.2013.01.003, 2013.

Lefebvre, C., Kalijn Peters, M., Wehrens, P. C., Brouwer, F. M., and van Roermund, H. L. M.: Thermal history and extensional exhumation of a high-temperature crystalline complex (Hırkadağ Massif, central Anatolia), Lithos, 238, 156-173, https://doi.org/10.1016/j.lithos.2015.09.021, 2015.

Li, S., Advokaat, E. L., van Hinsbergen, D. J. J., Koymans, M., Deng, C., and Zhu, R.: Paleomagnetic constraints on the Mesozoic-Cenozoic paleolatitudinal and rotational history of Indochina and South China: review and updated kinematic reconstruction, Earth-Sci. Rev., 171, 58-77, https://doi.org/10.1016/j.earscirev.2017.05.007, 2017.

Lucifora, S., Cifelli, F., Mattei, M., Sagnotti, L., Cosentino, D., and Roberts, A. P.: Inconsistent magnetic polarities in magnetiteand greigite-bearing sediments: understanding complex magnetizations in the Late Messinian in the Adana Basin (southern Turkey), Geochem. Geophy. Geosy., 13, Q10002, https://doi.org/10.1029/2012GC004248, 2012.

Lucifora, S., Cifelli, F., Rojay, F. B., and Mattei, M.: Paleomagnetic rotations in the Late Miocene sequence from the Çankırı Basin (central Anatolia, Turkey): the role of strike-slip tectonics, Turk. J. Earth Sci., 22, 778-792, 2013.

McFadden, P. L. and McElhinny, M. W.: The combined analysis of remagnetization circles and direct observations in palaeomagnetism, Earth Planet. Sc. Lett., 87, 161-172, 1988.

Meijers, M. J. M., Kaymakci, N., Van Hinsbergen, D. J. J., Langereis, C. G., Stephenson, R. A., and Hippolyte, J.C. C.: Late Cretaceous to Paleocene oroclinal bending in the central Pontides (Turkey), Tectonics, 29, TC4016, https://doi.org/10.1029/2009TC002620, 2010.

Meijers, M. J. M., van Hinsbergen, D. J. J., Dekkers, M. J., Altiner, D., Kaymakci, N., and Langereis, C. G.: Pervasive Palaeogene remagnetization of the central Taurides fold-and-thrust belt (southern Turkey) and implications for rotations in the Isparta Angle, Geophys. J. Int., 184, 1090-1112, 2011.

Meijers, M. J. M., Strauss, B. E., Özkaptan, M., Feinberg, J. M., Mulch, A., Whitney, D. L., and Kaymakci, N.: Age and paleoenvironmental reconstruction of partially remagnetized lacustrine sedimentary rocks (Oligocene Aktoprak Basin, central Anatolia, Turkey), Geochem. Geophy. Geosy., 17, 914-939, https://doi.org/10.1002/2015GC006209, 2016.

Menant, A., Jolivet, L., and Vrielynck, B.: Kinematic reconstructions and magmatic evolution illuminating crustal and mantle dynamics of the eastern Mediterranean region since the Late Cretaceous, Tectonophysics, 675, 103-140, 2016.

Moix, P., Beccaletto, L., Kozur, H. W., Hochard, C., Rosselet, F., and Stampfli, G. M.: A new classification of the Turkish terranes and sutures and its implication for the paleotectonic history of the region, Tectonophysics, 451, 7-39, https://doi.org/10.1016/j.tecto.2007.11.044, 2008.

Monod, O.: Recherches géologiques dans le Taurus occidental au Sud de Beysehir (Turquie), Univ. Paris Sud, Orsay, France, 1977.

MTA: Geological Map of Turkey, Scale 1:500,000, Mineral Research and Exploration Institute of Turkey, Ankara, 2002.

Mullender, T. A. T., Van Velzen, A. J., and Dekkers, M. J.: Continuous drift correction and separate identification of ferrimagnetic and paramagnetic contributions in thermomagnetic runs, Geophys. J. Int., 114, 663-672, 1993.

Mullender, T. A. T., Frederichs, T., Hilgenfeldt, C., de Groot, L. V., Fabian, K., and Dekkers, M. J.: Automated paleomagnetic and rock magnetic data acquisition with an in-line horizontal " $2 \mathrm{G}$ " system, Geochem. Geophy. Geosy., 17, 3546-3559, 2016.

Nikishin, A. M., Okay, A. I., Tüysüz, O., Demirer, A., Amelin, N., and Petrov, E.: The Black Sea basins structure and history: new model based on new deep penetration regional seismic data. Part 1: Basins structure and fill, Mar. Petrol. Geol., 59, 638-655, https://doi.org/10.1016/j.marpetgeo.2014.08.017, 2015.

Okay, A. I. and Nikishin, A. M.: Tectonic evolution of the southern margin of Laurasia in the Black Sea region, Int. Geol. Rev., 1-26, https://doi.org/10.1080/00206814.2015.1010609, 2015.

Okay, A. I. and Tüysüz, O.: Tethyan sutures of northern Turkey, Geol. Soc. Spec. Publ., 156, 475-515, https://doi.org/10.1144/GSL.SP.1999.156.01.22, 1999.

Okay, A. I., Sunal, G., Tüysüz, O., Sherlock, S., Keskin, M., and Kylander-Clark, A. R. C.: Low-pressure-high-temperature metamorphism during extension in a Jurassic magmatic arc, Central Pontides, Turkey, J. Metamorph. Geol., 32, 49-69, https://doi.org/10.1111/jmg.12058, 2014.

Oktay, F. Y.: Sedimentary and Tectonic History of the Ulukisla Area, Southern Turkey, University of London, London, 1973.

Oktay, F. Y.: Stratigraphy and geological history of Ulukısla and its surroundings, Bull. Turkish Geol. Soc., 25, 15-23, 1982.

Orbay, N. and Bayburdi, A.: Palaeomagnetism of dykes and tuffs from the Mesudiye region and rotation of Turkey, Geophys. J. Int., 59, 437-444, 1979.

Özdamar, Ş., Billor, M. Z., Sunal, G., Esenli, F., and Roden, M. F.: First U-Pb SHRIMP zircon and ${ }^{40} \mathrm{Ar} /{ }^{39} \mathrm{Ar}$ ages of metarhyolites from the Afyon-Bolkardag Zone, SW Turkey: implications for the rifting and closure of the Neo-Tethys, Gondwana Res., 24, 377-391, https://doi.org/10.1016/j.gr.2012.10.006, 2013.

Özgül, N.: Stratigraphy and tectonic evolution of the Central Taurides, Geol. Taurus Belt, 77-90, 1984. 
Parlak, O., Colakoglu, A., Donmez, C., Sayak, H., Yildirim, N., Turkel, A., and Odabasi, I.: Geochemistry and tectonic significance of ophiolites along the Izmir-Ankara-Erzincan Suture Zone in northeastern Anatolia, Geol. Soc. Spec. Publ., 372, 75105, https://doi.org/10.1144/SP372.7, 2012.

Passier, H. F., De Lange, G. J., and Dekkers, M. J.: Magnetic properties and geochemistry of the active oxidation front and the youngest sapropel in the eastern Mediterranean Sea, Geophys. J. Int., 145, 604-614, 2001.

Pichat, A., Hoareau, G., Callot, J.-P., and Ringenbach, J.-C.: Diagenesis of Oligocene continental sandstones in salt-walled minibasins - Sivas Basin, Turkey, Sediment. Geol., 339, 13-31, 2016.

Piper, J. D. A., Guersoy, H., Tatar, O., Isseven, T., and Kocyigit, A.: Palaeomagnetic evidence for the Gondwanian origin of the Taurides and rotation of the Isparta Angle, southern Turkey, Geol. J., 37, 317-336, 2002a.

Piper, J. D. A., Gürsoy, H., and Tatar, O.: Palaeomagnetism and magnetic properties of the Cappadocian Ignimbrite Succession, central Turkey and Neogene tectonics of the Anatolian collage, J. Volcanol. Geoth. Res., 117, 237-262, 2002b.

Piper, J. D. A., Koçbulut, F., Gürsoy, H., Tatar, O., Viereck, L., Lepetit, P., Roberts, A. P., and Akpınar, Z.: Palaeomagnetism of the Cappadocian Volcanic Succession, central Turkey: major ignimbrite emplacement during two short (Miocene) episodes and Neogene tectonics of the Anatolian collage, J. Volcanol. Geoth. Res., 262, 47-67, 2013.

Platzman, E. S., Tapirdamaz, C., and Sanver, M.: Neogene anticlockwise rotation of central Anatolia (Turkey): preliminary palaeomagnetic and geochronological results, Tectonophysics, 299, 175-189, 1998.

Poisson, A., Guezou, J. C., Ozturk, A., Inan, S., Temiz, H., Gürsöy, H., Kavak, K. S., and Özden, S.: Tectonic setting and evolution of the Sivas Basin, central Anatolia, Turkey, Int. Geol. Rev., 38, 838-853, https://doi.org/10.1080/00206819709465366, 1996.

Poisson, A., Vrielynck, B., Wernli, R., Negri, A., Bassetti, M.-A., Büyükmeriç, Y., Özer, S., Guillou, H., Kavak, K. S., Temiz, H., and Orszag-Sperber, F.: Miocene transgression in the central and eastern parts of the Sivas Basin (central Anatolia, Turkey) and the Cenozoic palaeogeographical evolution, Int. J. Earth Sci., 105, 339-368, https://doi.org/10.1007/s00531-015-1248-1, 2016.

Pourteau, A., Sudo, M., Candan, O., Lanari, P., Vidal, O., and Oberhänsli, R.: Neotethys closure history of Anatolia: insights from ${ }^{40} \mathrm{Ar}-{ }^{39} \mathrm{Ar}$ geochronology and $\mathrm{P}-\mathrm{T}$ estimation in highpressure metasedimentary rocks, J. Metamorph. Geol., 31, 585606, https://doi.org/10.1111/jmg.12034, 2013.

Ribes, C., Kergaravat, C., Bonnel, C., Crumeyrolle, P., Callot, J.-P., Poisson, A., Temiz, H., and Ringenbach, J.-C.: Fluvial sedimentation in a salt-controlled mini-basin: stratal patterns and facies assemblages, Sivas Basin, Turkey, Sedimentology, 62, 15131545, 2015.

Robertson, A. H., Parlak, O., and Ustaömer, T.: Melange genesis and ophiolite emplacement related to subduction of the northern margin of the Tauride-Anatolide continent, central and western Turkey, Special Publications, Geological Society, London, 311, 9-66, 2009.

Robertson, A. H. F.: Overview of the genesis and emplacement of Mesozoic ophiolites in the Eastern Mediterranean
Tethyan region, Lithos, 65, 1-67, https://doi.org/10.1016/S00244937(02)00160-3, 2002.

Saribudak, M.: New results and a palaeomagnetic overview of the Pontides in northern Turkey, Geophys. J. Int., 99, 521-531, 1989.

Sarıkaya, M. A., Yıldırım, C., and Çiner, A.: No surface breaking on the Ecemiş Fault, central Turkey, since Late Pleistocene ( $\sim 64.5 \mathrm{ka})$; new geomorphic and geochronologic data from cosmogenic dating of offset alluvial fans, Tectonophysics, 649, 33 46, 2015.

Schildgen, T. F., Cosentino, D., Caruso, a., Buchwaldt, R., Yıldırım, C., Bowring, S. A., Rojay, B., Echtler, H., and Strecker, M. R.: Surface expression of Eastern Mediterranean slab dynamics: neogene topographic and structural evolution of the southwest margin of the Central Anatolian Plateau, Turkey, Tectonics, 31, TC2005, https://doi.org/10.1029/2011TC003021, 2012.

Şengör, A. M. C. and Yılmaz, Y.: Tethyan evolution of Turkey: a plate tectonic approach, Tectonophysics, 75, 181-241, 1981.

Sümengen, M., Ünay, E., Sarac, G., de Bruijn, H., Terlemez, I., and Gürbüz, M.: New neogene rodent assemblages from Anatolia (Turkey), in: European Neogene mammal chronology, Springer US, 61-72, 1990.

Tatar, O., Piper, J. D., and Gürsoy, H.: Palaeomagnetic study of the Erciyes sector of the Ecemiş Fault Zone: neotectonic deformation in the southeastern part of the Anatolian Block, Special Publications, Geological Society, London, 173, 423-440, 2000.

Tauxe, L.: Essentials of Paleomagnetism, Univ. of California Press, Berkeley, p. 506, 2010.

Tauxe, L. and Watson, G. S.: The fold test: an eigen analysis approach, Earth Planet. Sc. Lett., 122, 331-341, 1994.

Topuz, G., Okay, A. I., Altherr, R., Schwarz, W. H., Sunal, G., Altinkaynak, L., and Altınkaynak, L.: Triassic warm subduction in northeast Turkey: evidence from the Ağvanis metamorphic rocks, Isl. Arc., 23, 181-205, https://doi.org/10.1111/iar.12068, 2014.

Torsvik, T. H., Van der Voo, R., Preeden, U., Mac Niocaill, C., Steinberger, B., Doubrovine, P. V., van Hinsbergen, D. J. J., Domeier, M., Gaina, C., Tohver, E., and Meert, J. G.: Phanerozoic polar wander, palaeogeography and dynamics, Earth-Sci Rev., 114, 325-368, 2012.

Ünlügenç, U. C. and Akıncı, A. C.: Sedimentary development of the Oligocene Karsant? Basin, southern Turkey, in its regional tectonic setting, J. Asian Earth Sci., 105, 173-191, 2015.

Ustaömer, T. and Robertson, A. H. F.: Tectonic-sedimentary evolution of the north Tethyan margin in the central Pontides of northern Turkey, AAPG Memoir., 68, 255-290, 1997.

Ustaömer, T. and Robertson, A. H. F.: Late Palaeozoic-Early Cenozoic tectonic development of the eastern Pontides (Artvin area), Turkey: stages of closure of Tethys along the southern margin of Eurasia, Geol. Soc. Spec. Publ., 340, 281-327, 2010.

Van der Voo, R.: Paleomagnetism and the Alpine tectonics of Eurasia IV: Jurassic, Cretaceous and Eocene pole positions from northeastern Turkey, Tectonophysics 6, 251-269, 1968.

Van der Voo, R.: The reliability of paleomagnetic data, Tectonophysics, 184, 1-9, 1990.

van Hinsbergen, D. J. J., Maffione, M., Plunder, A., Kaymakci, N., Ganerød, M., Hendriks, B. W. H., Corfu, F., Gürer, D., de Gelder, G. I. N. O., Peters, K., McPhee, P. J., Brouwer, F. M., Advokaat, E. L., and Vissers, R. L. M.: Tectonic evolu- 
tion and paleogeography of the Kırşehir Block and the Central Anatolian Ophiolites, Turkey, Tectonics, 35, 983-1014, https://doi.org/10.1002/2015tc004018, 2016.

Van Velzen, A. J. and Zijderveld, J. D. A.: Effects of weathering on single-domain magnetite in Early Pliocene marine marls, Geophys. J. Int., 121, 267-278, 1995.

Westaway, R. and Arger, J.: Kinematics of the Malatya-Ovacık fault zone, Geodinamica Acta, 14, 103-131, 2001.

Whitney, D. L. and Hamilton, M. A.: Timing of high-grade metamorphism in central Turkey and the assembly of Anatolia, J. Geol. Soc. Lond., 161, 823-828, 2004.
Yilmaz, A. and Yilmaz, H.: Characteristic features and structural evolution of a post collisional basin: the Sivas Basin, central Anatolia, Turkey, J. Asian Earth Sci., 27, 164-176, 2006.

Zijderveld, J. D. A.: AC demagnetization of rocks: analysis of results, in: Methods in Paleomagnetism, edited by: Collinson, D. W. and Creer, K. M., Elsevier, Amsterdam, 254286, 1967. 